\title{
Stoichiometry among bioactive trace metals in the Chukchi and Beaufort Seas
}

\section{$\operatorname{AUTHOR}(S)$ :}

Cid, Abigail Parcasio; Nakatsuka, Seiji; Sohrin, Yoshiki

\section{CITATION:}

Cid, Abigail Parcasio ...[et al]. Stoichiometry among bioactive trace metals in the Chukchi and Beaufort Seas. Journal of Oceanography 2012, 68(6): 985-1001

\section{ISSUE DATE:}

2012-12

URL:

http://hdl.handle.net/2433/166328

\section{RIGHT:}

The final publication is available at www.springerlink.com; This is not the published version. Please cite only the published version.; この論文 は出版社版でありません。引用の際には出版社版をご確認ご利用くだ さい。 
1 Stoichiometry among bioactive trace metals in the Chukchi and Beaufort Seas

2

Abigail Parcasio Cid, Seiji Nakatsuka and Yoshiki Sohrin*

4

Institute for Chemical Research, Kyoto University, Uji, Kyoto 611-0011

6

*Corresponding author. E-mail: sohrin@scl.kyoto-u.ac.jp

Telephone: 81-774-38-3100; Fax: 81-774-38-3099

Abstract

The distribution of $\mathrm{Al}, \mathrm{Mn}, \mathrm{Fe}, \mathrm{Co}, \mathrm{Ni}, \mathrm{Cu}, \mathrm{Zn}, \mathrm{Cd}$ and $\mathrm{Pb}$ in seawater was investigated in the Chukchi and Beaufort Seas of the western Arctic Ocean in September

13 2000. The unfiltered and filtered seawater samples were used for determination of total 14 dissolvable metal (TDM) and dissolved metal (DM), respectively. The concentration of labile particulate metal (LPM) was estimated with the difference between that of TDM and DM. The concentrations of TDAl, TDMn, TDFe, TDCo and TDPb varied substantially in the study area. The high concentrations occurred at stations near the Bering Strait, in the Mackenzie delta, and above reductive sediments on the shelf and slope. These elements were mostly dominated by labile particulate species, such as Fe-Mn oxides and species adsorbed on terrestrial clay. DCo was correlated with DMn over the study area $(r=0.78, n$

$21=135$ ), and the slope of the regression line was 27 times higher at a pelagic station than at a shelf station. TDNi, TDCu, TDZn and TDCd showed relatively small variations and were generally dominated by dissolved species. There was a moderate correlation between DCd and phosphate for all samples $(r=0.79)$, whereas there were no significant correlation 
1 most stations except those near the Bering Strait $\left(R^{2}=0.95, n=126\right)$. These results suggest

2 that biogeochemical cycling including uptake by phytoplankton and remineralization from

3 settling particles has only minor control over the distribution of trace metals in this area.

4 Using the present data, the annual input of bioactive trace metals form the Bering Strait and

5 the Mackenzie River was estimated. Also the trace metal compositions of major water

6 masses were evaluated. The dissolved elemental ratio was $\mathrm{P}: \mathrm{Al}: \mathrm{Mn}: \mathrm{Fe}: \mathrm{Co}: \mathrm{Ni}: \mathrm{Cu}$ :

$7 \mathrm{Zn}: \mathrm{Cd}=1: 1.2 \times 10^{-2}: 4.4 \times 10^{-4}: 1.4 \times 10^{-3}: 3.7 \times 10^{-5}: 3.7 \times 10^{-3}: 1.4 \times 10^{-3}: 4.5 \times 10^{-3}:$

$82.2 \times 10^{-4}$ for Canada Basin deep water $(\mathrm{CBDW})$. This ratio was significantly different from

9 that for Pacific deep water and Bering Sea water, suggesting substantial modification of the trace metal compositions of seawater in the study area.

Keywords: Arctic Ocean, Chukchi Sea, Beaufort Sea, seawater, bioactive trace metals, total dissolvable species, dissolved species, labile particulate species, speciation, stoichiometry.

1. Introduction to organisms and/or highly toxic at a high concentration. In recent decades, studies in chemical oceanography have revealed that these elements are important as limiting factors of biological productivity and as tracers of biogeochemical processes (SCOR Working Group 2007; Sohrin and Bruland 2011). However, our knowledge is still limited on their global distributions and time-dependent dynamics. This is especially true to the Arctic Ocean that is characterized by ice cover and harsh weather. Moore $(1981 ; 1983)$ has reported the first vertical profiles of dissolved (D) $\mathrm{Al}, \mathrm{Fe}, \mathrm{Cu}, \mathrm{Zn}$ and $\mathrm{Cd}$ in the central Arctic Ocean (Makarov Basin), suggesting that the high surface concentrations of $\mathrm{Cu}, \mathrm{Zn}$ and $\mathrm{Cd}$ were related to 
1 water. Danielson and Westerlund (1983) observed the vertical profiles of total dissolvable

2 (TD) $\mathrm{Fe}, \mathrm{Ni}, \mathrm{Cu}, \mathrm{Zn}$ and $\mathrm{Cd}$ in the eastern Arctic Ocean. Mart et al. (1984) investigated the

3 total dissolvable concentrations of $\mathrm{Ni}, \mathrm{Cu}, \mathrm{Cd}$ and $\mathrm{Pb}$ in surface and deep water collected

4 from the eastern Arctic Ocean. Yeats and Westerlund (Yeats 1988; Yeats and Westerlund

5 1991) reported the concentrations of TDMn, TDCo, TDNi, TDCu, TDCd and DMn near the

6 Canadian Ice Island. Measures (1999) determined the distribution of reactive $\mathrm{Al}$ and $\mathrm{Fe}$ in

7 surface water along a section from the Canada Basin to the Eurasian Basin, suggesting that

8 ice-rafted sediment may be an important source for Al and Fe. Substantial advancements in

9 the study of Al, Mn and Fe were attained during an expedition of R.V. Polarstern in 2007.

10 Ocean transects of DAl were determined in the Eurasian part of the Arctic Ocean, showing a

11 strong correlation between DAl and Si (Middag et al. 2009). The elevated DMn in the surface layer was related to fresh water input, and a deep maximum of DMn in the Nansen

13 Basin was ascribed to hydrothermal input over the Gakkel Ridge (Middag et al. 2011). The distribution of DFe in the Arctic shelf seas (Barents, Kara and Laptev Seas) and in the surface waters of the central Arctic Ocean revealed the impact of river water and ice-melt (Klunder et al. 2012a), and that in deep water of the Nansen, Amundsen and Makarov Basins showed input from the shelf seas and slopes, effect of hydrothermal activity, and scavenging in the deepest part (Klunder et al. 2012b). Thuróczy et al. (2011) investigated the size-fractionated speciation and ligand characteristics of Fe. Lastly, Nakayama et al. (2011) reported the vertical distribution of $\mathrm{DFe}$ and TDFe throughout the water column in the western Arctic Ocean (Chukchi Sea and Canada Basin).

We participated in the MR00-K06 cruise of R/V Mirai and collected clean seawater samples for trace metal study in the Bering, Chukchi and Beaufort Seas in September 2000. In previous work, we reported the distribution of dissolved, total dissolvable and labile particulate (LP) species for $\mathrm{Al}, \mathrm{Mn}, \mathrm{Fe}, \mathrm{Co}, \mathrm{Ni}, \mathrm{Cu}, \mathrm{Zn}, \mathrm{Cd}$ and $\mathrm{Pb}$ in the Bering Sea (Cid et al. 
1 2011). Here we present their distribution in the Chukchi and Beaufort Seas to provide a

2 comprehensive view on biogeochemistry of the nine elements in the western Arctic Ocean.

$4 \quad 2 . \quad$ Sample Collections and Methods

5 2.1. Sampling locations

Seawater samples for this study were obtained during the MR00-K06 cruise of R/V

Mirai from 2 stations (A001 and A002) near the Bering Strait, 2 stations (A005 and A009) in the Barrow Canyon, 2 stations (A018 and A020) in the Mackenzie Trough, 6 stations (A003, A016, A022, A039, A042 and A054) on the slope of the Beaufort Sea, and 1 station (A023) in 10 the Canada Basin (Fig. 1).

2.2. Water sampling and analytical methods

The water sampling and analytical methods are almost identical with that in the previous work (Cid et al. 2011). Seawater samples were collected with Niskin-X bottles that have been thoroughly cleaned with detergent and $\mathrm{HCl}$ and mounted on a CTD-rosette water 16 sampling system (General Oceanics), the flame of which was finished with epoxy paint.

17 Upon retrieval of the CTD-rosette water sampling system, the seawater samples were transferred to $500 \mathrm{ml}$ pre-cleaned low-density polyethylene bottles (LDPE, Nalge Nunc) on the deck using a silicon tube and filling bell (Nalge Nunc) to avoid contamination of airborne particles. The samples were immediately brought into a clean room laboratory of the vessel.

21 An aliquot of seawater $(250 \mathrm{ml})$ was filtered through a $0.2 \mu \mathrm{m}$ Nuclepore filter (Coaster) using a closed filtration system and $\mathrm{HCl}$ (TAMAPURE AA-10, Tama Chemicals) was added resulting in a final concentration of $0.01 \mathrm{M}$ and $\mathrm{pH}$ 2.2. This subsample was used for the

24 determination of DMs. The other aliquot of seawater $(250 \mathrm{ml})$ was not filtered and a mixed acid was added to achieve a final concentration of $0.01 \mathrm{M} \mathrm{HCl}$ and $0.002 \mathrm{M} \mathrm{HF}$ 
1 (TAMAPURE AA-10), and used for the determination of TDMs. The seawater samples

2 were stored at room temperature in our laboratory more than 8 years until analysis. Here we

3 defined the labile particulate metal (LPM) as the difference between that of TDM and DM,

4 which would contain species such as those adsorbed on clay minerals, iron and manganese

5 oxyhydroxides, and those incorporated in organisms (Ezoe et al. 2004).

The details of the analytical method for bioactive trace metals have been reported elsewhere (Sohrin et al. 2008). Preconcentration of the trace metals was performed using the chelating resin on which ethylenediaminetriacetic and iminodiacetic acids were immobilized (NOBIAS CHELATE-PA1, Hitachi High-Technologies). Finally, the trace metals were eluted with $15 \mathrm{ml}$ of $1 \mathrm{M} \mathrm{HNO}_{3}$ (TAMAPURE AA-10). Concentrations of DMs and TDMs in the eluate were determined using an inductively coupled plasma mass spectrometer (Elan DRC II, Perkin Elmer) by a calibration curve method. The isotopes used for the determination were ${ }^{27} \mathrm{Al},{ }^{55} \mathrm{Mn},{ }^{54} \mathrm{Fe},{ }^{59} \mathrm{Co},{ }^{60} \mathrm{Ni},{ }^{65} \mathrm{Cu},{ }^{68} \mathrm{Zn},{ }^{114} \mathrm{Cd}$ and ${ }^{208} \mathrm{~Pb}$. Other isotopes were also measured for cross checking except mono-isotopic Al, Mn and Co.

The detection limits by ICP-MS after preconcentration with a concentration factor of 8 were $0.1 \mathrm{nmol} \mathrm{kg}^{-1} \mathrm{Al}, 0.05 \mathrm{nmol} \mathrm{kg}^{-1} \mathrm{Mn}, 0.03 \mathrm{nmol} \mathrm{kg}^{-1} \mathrm{Fe}, 6 \mathrm{pmol} \mathrm{kg}{ }^{-1} \mathrm{Co}, 0.1 \mathrm{nmol}$ $\mathrm{kg}^{-1} \mathrm{Ni}, 0.03 \mathrm{nmol} \mathrm{kg}{ }^{-1} \mathrm{Cu}, 0.3 \mathrm{nmol} \mathrm{kg}{ }^{-1} \mathrm{Zn}, 0.005 \mathrm{nmol} \mathrm{kg}{ }^{-1} \mathrm{Cd}$, and $0.2 \mathrm{pmol} \mathrm{kg}^{-1} \mathrm{~Pb}$. The average percent recovery with sd was typically $100 \pm 15 \%(n=3)$ for each metal on the experiments using seawater with and without metal-spike. The average concentrations with sd in seawater reference material NASS-5 (National Research Council of Canada) by this method were $3.59 \pm 0.25 \mathrm{nmol} \mathrm{kg}^{-1}$ for $\mathrm{Al}, 13.0 \pm 0.23 \mathrm{nmol} \mathrm{kg}^{-1}$ for $\mathrm{Mn}, 2.85 \pm 0.18 \mathrm{nmol}$ $\mathrm{kg}^{-1}$ for Fe, $145 \pm 5 \mathrm{pmol} \mathrm{kg}^{-1}$ for $\mathrm{Co}, 4.72 \pm 0.08 \mathrm{nmol} \mathrm{kg}^{-1}$ for Ni, $4.49 \pm 0.15 \mathrm{nmol} \mathrm{kg}^{-1}$ for $\mathrm{Cu}, 1.66 \pm 0.09 \mathrm{nmol} \mathrm{kg}^{-1}$ for $\mathrm{Zn}, 0.176 \pm 0.001 \mathrm{nmol} \mathrm{kg}^{-1}$ for $\mathrm{Cd}$, and $35 \pm 1 \mathrm{pmol} \mathrm{kg}^{-1}$ for $\mathrm{Pb}(n=3)$. The results agreed with the certified values, while there was no certified value for Al. Our method was also validated using the SAFe reference materials of seawater 
1 (Sohrin et al. 2008).

Temperature (T) was measured with the CTD. Salinity (S) was determined by conductivity on board the vessel (Participants of MR00-K06 2000). Dissolved oxygen was determined by the Winkler method. Macronutrients were measured on board with an AutoAnalyzer (TRAACSS). Chlorophyll $a$ (Chl. a) was determined by fluorometry. Ocean Data View (Schlitzer, R., http://odv.awi.de, 2012) was utilized for data analysis and preparation some figures.

\section{Results}

\subsection{Hydrography}

Schematics of water masses and currents are shown in Fig. 1 (Grebmeier et al. 2006). Pacific water inflow from the Bering Sea consists of Alaska Coastal Water (ACW) on the eastern side, Anadyr Water (AW) on the western side, and Bering Shelf Water (BSW) lying between ACW and AW. As these waters flow north through the Bering Strait, AW and BSW mix to form a modified Bering Shelf-Anadyr Water (BSAW). An annual mean transport of the Pacific water inflow is assumed to be $0.8 \mathrm{~Sv}$ with salinity of 32.5 (Woodgate and Aagaard 2005). This is an important source of heat, freshwater and nutrients into the Arctic Ocean. Shelf transformation processes modify the physical and biogeochemical properties of Pacific waters as they cross the Chukchi shelf. For the Chukchi and Beaufort regions, current transport from the shelves to slope and deep basins occurs primarily through the Barrow and Herald Canyons, with subsequent transport into the basin via currents flowing eastward along the continental slope, eddies generated along the slope, and/or by the effects of surface wind-forcing. The eastward flow consists of modified BSAW, ACW and Atlantic Intermediate Water (AIW). The Mackenzie River is the largest river that flows to the Beaufort Sea with a water discharge of $249-333 \mathrm{~km}^{3} \mathrm{y}^{-1}$ (Dittmar and Kattner 2003). In the 
1 Canadian Basin, there are anticyclonic (westward) surface circulation and cyclonic deep

2 circulation (Jones et al. 1995). The Arctic Ocean is relatively well ventilated above the ridge

3 depth of the Lomonosov Ridge (Talley et al. 2011). Deep water in the Canadian Basin is

4 called Canadian Basin Deep Water (CBDW), which has a mean age of 450 years below the 5 ridge depth.

Figure 2 shows a potential temperature-salinity diagram for the stations except A018 and A020. Salinity of surface water decreased to 9.8 at A018 and 17.8 at A020, indicating input of freshwater from the Mackenzie River. According to Fig. 2, several water masses can be identified (Aagaard et al. 1981; Codispoti et al. 2005; Wang et al. 2006); (1) surface water (SW), extending from the surface to $\sim 50 \mathrm{~m}$, with salinities of $26-32$ and temperatures of -1 to $7^{\circ} \mathrm{C},(2)$ cold and salty water from $\sim 50$ to $\sim 200 \mathrm{~m}$, named as the upper halocline layer (UHL), with salinities of $32.5-33.6$ and temperatures of -1.7 to $-1.3^{\circ} \mathrm{C}$, (3) warmer and more saline water from $\sim 150$ to $\sim 250 \mathrm{~m}$, named as the lower halocline layer (LHL), with salinities of $34.0-34.4$ and temperatures of -0.9 to $-0.5^{\circ} \mathrm{C}$, (4) AIW from $\sim 200$ to $\sim 775 \mathrm{~m}$, with salinities of 34.6-34.9 and temperatures of 0 to $0.9^{\circ} \mathrm{C}$, and (5) CBDW, below $1000 \mathrm{~m}$ depth, with salinities of $>34.9$ and temperatures of $<0^{\circ} \mathrm{C}$.

\subsection{Distribution of bioactive trace metals near the Bering Strait}

The data of trace metals are summarized in Appendix Table 1. Obviously contaminated and/or questionable values were removed from the following discussion, taking account of oceanographic consistency. The concentration ranges for TDM and DM in each region are given in Table 1. The vertical profiles of TDMs at A001 and A002 are compared with the profile of station BR013 $\left(167^{\circ} \mathrm{W}, 64.0^{\circ} \mathrm{N}\right)$ in the northern Bering Sea (Cid et al. 2011) in Fig. 3. The vertical profiles of DMs and oceanographic parameters are presented in Appendix Fig. 1. The concentrations of labile $\mathrm{Al}$ at $168.8^{\circ} \mathrm{W}, 67.8^{\circ} \mathrm{N}$ were $16-22 \mathrm{nM}$ 
1 (Measures 1999), which were slightly higher than those of our DAl. At stations A001 and

2 A002, labile particulate species occupied $>94 \%$ for TDAl, $>60 \%$ for $\mathrm{TDMn},>99 \%$ for TDFe,

$3>44 \%$ for $\mathrm{TDCo}$, and $>45 \%$ for $\mathrm{TDPb}$. This was similar to the situation observed on the

4 Bering Sea shelf (Cid et al. 2011). Most of TDMs and DMs gave higher concentrations at

5 A002 than those at BR013 and A001 as well as phosphate and dissolved inorganic nitrogen

6 (DIN; the sum of nitrate, nitrite and ammonium) that was dominated by ammonium (Fig. 3),

7 suggesting additional input from the underlying sediments in the Chukchi shelf.

3.3. Distribution of bioactive trace metals in the Barrow Canyon

Stations A009 and A005 in the Barrow Canyon were characterized by high concentrations of Mn and Co (Table 1). LPMn accounted for 18-70\% of TDMn, and LPCo accounted for $7-81 \%$ of TDCo. TDAl and TDFe were also dominated by labile particulate species; LPAl accounted for $56-99 \%$ of TDAl, and LPFe accounted for more than $93 \%$ of TDFe. In contrast, TDNi, TDCu, TDZn and TDCd were dominated by dissolved species.

Figure 4 shows the sectional distributions of TDMs and potential temperature from the

16 Barrow Canyon to continental slope (stations A009, A005 and A003). The sectional

17 distributions of DMs and oceanographic parameters are presented in Appendix Fig. 2. TDAl, TDMn, TDFe and TDCo were rich at shelf stations and rapidly decreased between A005 and A003 (Fig. 4). TDAl and TDFe showed a strong correlation $(r=0.90, n=34)$, suggesting dominance of terrestrial mineral particles. TDCo showed moderate correlations with TDMn $(r=0.80)$ and TDFe $(r=0.81)$. DMn, DCo and ammonium showed moderate correlations with each other $(r=0.73-0.86)$. This is ascribed to the effect of denitrification and manganese reduction in sediments of the shelf region. High concentrations of $\mathrm{DNi}, \mathrm{DCu}$, DZn and DCd were observed at 50-200 m depth at A003 in accordance with the maximums 
$1 \quad(r=0.71)$ and phosphate $(r=0.69)$. Also DNi showed moderate to strong correlations with

2 DCd $(r=0.87)$ and DCu $(r=0.77)$. DZn did not show such a correlation. TDPb was

3 dominated by the labile particulate fraction and did not show a significant correlation with the

4 other parameters.

6 3.4. Distribution of bioactive trace metals in the Mackenzie Trough

$\mathrm{Al}, \mathrm{Co}, \mathrm{Ni}, \mathrm{Cu}$, and $\mathrm{Zn}$ showed the highest concentrations at station $\mathrm{A} 018$ in the Mackenzie Trough (Table 1). Figure 5 shows the sectional distributions of TDMs and salinity from the Mackenzie Trough to continental slope (stations A018, A020 and A022). The sectional distributions of DMs and oceanographic parameters are presented in Appendix

Fig. 3. The concentrations of TDMs except TDCd were elevated at A018, giving significant negative correlations with $\mathrm{S}(r=-0.63--0.84, n=25)$ and positive correlations with each other $(r=0.71-0.99)$. TDAl, TDMn, TDFe and TDCo were dominated by labile particulate species, and their LPMs showed strong correlations $(r=0.95-0.98)$. This suggests that these metals are mostly supplied as particulate forms from the Mackenzie River. DMn, DFe, DCo, nitrite and ammonium also showed moderate correlations with each other $(r=0.71-0.88)$, whereas there were no significant correlations with DAl. This means substantial amounts of DMn, DFe and DCo are supplied through reductive dissolution from the sediments. TDNi, TDCu, TDZn and TDCd were dominated by dissolved species. It is likely that these metals are mainly supplied as dissolved species from the Mackenzie River. DNi and DCu showed moderate correlations with DMn, DCo, nitrite and ammonium $(r=0.74-0.93)$, suggesting $\mathrm{DNi}$ and $\mathrm{DCu}$ are also released from the sediments through manganese reduction. Only DCd showed strong correlations with silicate and phosphate $(r=0.82-0.84)$. DZn showed weak correlations with $\mathrm{DCo}, \mathrm{DNi}$ and $\mathrm{DCu}(r=0.62-0.69)$. There was a moderate correlation between $\mathrm{DPb}$ and $\mathrm{DFe}(r=0.80)$. 
2 3.5. Distribution of bioactive trace metals on the slope of the Beaufort Sea

At the stations on the slope of the Beaufort Sea, the concentrations for Al, Mn, Fe,

4 Co and $\mathrm{Zn}$ were generally between those at shelf stations and those at a station in the Canada

5 Basin (Table 1). The concentrations for $\mathrm{Ni}, \mathrm{Cu}$ and $\mathrm{Cd}$ above the slope of the Beaufort Sea

6 were comparable with those in the Canada Basin. The vertical profiles of TDMs at A054, 7 A003, A016 and A022 are compared in Fig. 6 to examine east-west differences. The vertical

8 profiles of DMs and oceanographic parameters are presented in Appendix Fig. 4. TDAl,

9 TDMn, TDFe and TDCo showed maximums at $\sim 225 \mathrm{~m}$ depth at station A054, which was

10 within the UHL and just below the maximums of silicate, nitrate and phosphate at $\sim 200 \mathrm{~m}$

11 depth. Nakayama et al. (Nakayama et al. 2011) reported the vertical profiles of TDFe and DFe at a slope station $\mathrm{B} 2\left(162^{\circ} \mathrm{W}, 74.5^{\circ} \mathrm{N}\right)$ in September 2008 , which was located northwest of A054. The concentrations were 3.0-48 $\mathrm{nM}$ for TDFe and 0.50-1.3 nM for DFe with maximums at $\sim 175 \mathrm{~m}$ depth, which were also located in the UHL and just below the maximums of silicate and phosphate at $\sim 125 \mathrm{~m}$ depth. Thus the vertical profiles of TDFe and DFe were similar between station A054 in 2000 and station B2 in 2008, whereas the concentrations were significantly lower for B2. TDA1, TDMn, TDFe and TDCo showed three maximums at $\sim 25,200$ and $500 \mathrm{~m}$ depths at A003. The middle depth maximums were located in the LHL. The middle depth maximums appeared at 120 140 m depths corresponding to the UHL at A016. Broad maximums of TDAl, TDMn, TDFe and TDCo occurred in the upper water column above $180 \mathrm{~m}$ depth at A022. These results indicate that the distribution of TDAl, TDMn, TDFe and TDCo is highly influenced by local inputs. Correlation was studied for 6 stations (the above 4 stations plus A042 and A039). At these stations strong correlations were observed between TDAl and TDFe $(r=0.82, n=67)$ and between DMn and DCo $(r=0.81)$. The concentrations of DMn and TDCo were relatively 
1 low below $180 \mathrm{~m}$ at A022 and comparable to those observed at the Canadian Ice Island in 2 June 1985 (Yeats and Westerlund 1991).

TDCd was dominated by DCd, which was strongly correlated with silicate and

4 phosphate $(r=0.91-0.90)$. The maximum concentration occurred at $70-225 \mathrm{~m}$ depths

5 corresponding to the UHL. The maximum concentrations were higher at western stations.

6 TDNi, TDCu and TDZn were also mostly dominated by dissolved species. DNi, DCu and

7 DCd showed moderate to strong correlations with each other $(r=0.64-0.89)$. However, the

8 surface depletion was generally weak for DNi and DCu compared to DCd and nutrients, and

9 the maximum concentrations of $\mathrm{DNi}$ and $\mathrm{DCu}$ were higher at eastern stations. The latter is

10 probably due to input from the Mackenzie River. Although $\mathrm{Zn}$ shows a nutrient type profile

11 in the Atlantic and Pacific Oceans as well as $\mathrm{Ni}$ and $\mathrm{Cd}$, the profiles of $\mathrm{Zn}$ in this area were

12 substantially different from those of nutrients, $\mathrm{Ni}, \mathrm{Cu}$ and $\mathrm{Cd}$. The concentrations of TDNi,

$13 \mathrm{TDCu}, \mathrm{TDZn}$ and TDCd were relatively low below $200 \mathrm{~m}$ at A022 and comparable to those

14 observed at the Canadian Ice Island in June 1985 (Yeats and Westerlund 1991).

$\mathrm{TDPb}$ did not show significant correlations with any parameters. $\mathrm{TDPb}$ was generally dominated by dissolved species, whereas considerably high concentrations of LPPb were observed at some depths in the upper water column $(<300 \mathrm{~m})$.

\subsection{Distribution of bioactive trace metals in the Canada Basin}

Generally, the bioactive trace metals showed the lowest concentrations at station

21 A023 in the Canada Basin (Table 1). The vertical profiles of TDMs and DMs at A023 are

22 plotted in Fig. 7. The vertical profiles of oceanographic parameters are presented in 23 Appendix Fig. 5. DAl increased with depth at A023. The profile was consistent with that 24 of DAl observed at LOREX station (Moore 1981) and in the Nansen, Amundsen and 25 Makarov Basins (Middag et al. 2009). However, there was a break on the DAl profile at 
$12000 \mathrm{~m}$ depth at A023, where there was a break on the profile of potential temperature.

2 Middag et al. (Middag et al. 2009) reported strong correlations between DAl and silicate for

3 intermediate $(\sim 150-2000 \mathrm{~m})$ and deep $(>2000 \mathrm{~m})$ waters. DAl at A023 is plotted against

4 silicate in Fig. 8. The upper $300 \mathrm{~m}$ water column contained high concentrations of silicate

5 and there was no correlation between DAl and silicate. The correlations between DAl and

6 silicate were as follows:

7 for intermediate $(500-1750 \mathrm{~m})$ water,

$\left[\mathrm{DAl} \mathrm{nmol} \mathrm{kg}{ }^{-1}\right]=2.8\left[\mathrm{Si} \mu \mathrm{mol} \mathrm{kg} \mathrm{kg}^{-1}\right]-18.8 \quad R^{2}=0.96, n=6$

9 for deep ( $>2000 \mathrm{~m})$ water

$$
\left[\mathrm{DAl} \mathrm{nmol} \mathrm{kg}{ }^{-1}\right]=3.3\left[\mathrm{Si} \mu \mathrm{mol} \mathrm{kg}{ }^{-1}\right]-30.7 \quad R^{2}=0.96, n=5
$$

11 The slope for intermediate water was higher than in the other basins (1.9-2.2) and that for

12 deep water was considerably lower than in the other basins (7.4-13.5) (Middag et al. 2009).

13 These results may be related to deep water circulation. The Canada basin is separated from

14 the Makarov Basin by the Mendeleyev-Alpha Ridge by a $\sim 2000 \mathrm{~m}$ sill depth. It is reported

15 that the Makarov Basin is well ventilated by dense shelf water originating in the Barents,

16 Kara and Laptev Seas, whereas the Canada basin is relatively more isolated from this

17 ventilation source (Swift et al. 1997). TDAl became systematically lower than DAl below $1500 \mathrm{~m}$ depth at A023. Such abnormal inversion was significant only at this station. It is likely that TDAl in deep water samples was underestimated. For most TD samples, added HF was consumed to dissolve silicate particles and to form hexafluorosilicate. At this 21 station, terrigenous silicate particles occurred at a low concentration. It may be possible that 22 the remaining fluoride ions formed the complex with $\mathrm{Al}$ and interfered with the preconcentration.

TDMn, TDFe and TDCo showed maximums at $\sim 175 \mathrm{~m}$ depth of the UHL and decreased with depth. TDMn and TDFe were dominated by a labile particulate fraction 
$1 \quad(>51 \%$ for $\mathrm{Mn}$ and $>78 \%$ for $\mathrm{Fe})$, whereas TDCo consisted of comparable amounts of 2 dissolved and labile particulate species. TDMn showed strong correlations not only with

3 TDFe and TDCo but also with TDNi, TDCu and TDCd $(r=0.81-0.93, n=23)$. LPMn,

4 LPFe and LPCo also showed strong correlations each other $(r=0.86-0.95)$. DMn gave a

5 surface maximum at $25 \mathrm{~m}$ depth and decreased with depth. The profile was consistent with

6 observations in the Nansen, Amundsen and Makarov Basins (Thuróczy et al. 2011). The

7 average TDFe concentration with sd was $14 \pm 2 \mathrm{nmol} \mathrm{kg}^{-1}$ in CBDW at A023. This value

8 was higher than the TDFe concentration of $\sim 8 \mathrm{nmol} \mathrm{kg}^{-1}$ in CBDW in the western Canada

9 Basin (Nakayama et al. 2011) and 1.5-5.5 $\mathrm{nmol} \mathrm{kg}^{-1}$ in the Nansen, Amundsen and Makarov

10 Basins (Middag et al. 2011). It is likely that the long storage of acidified samples with a

11 small amount of HF until preconcentration resulted in more complete dissolution of LPFe in this work. DFe showed a relatively uniform profile at A023, and the baseline concentration was similar to that in the western Canada Basin (Nakayama et al. 2011) and in the other basins of the Arctic Ocean (Klunder et al. 2012b; Thuróczy et al. 2011). The profile of DCo was mostly similar to that of DMn $(r=0.83)$. DCo also showed strong correlations with DNi and DCu $(r=0.87-0.92)$. The break at $2000 \mathrm{~m}$ depth on the profile was observed for DMn, DFe and DCo as well as DAl. A broad maximum of DMn occurred below $2000 \mathrm{~m}$. DFe and DCo gave a maximum above $2000 \mathrm{~m}$. Another maximum of DFe was observed at $\sim 2500 \mathrm{~m}$.

TDNi, TDCu and TDCd showed similar profiles with phosphate and silicate. Although phosphate and silicate increased with depth in deep water, the concentrations of TDNi, TDCu and TDCd were more constant. TDNi, TDCu and TDCd were dominated by dissolved species $(>89 \%$ for $\mathrm{Ni},>82 \%$ for $\mathrm{Cu}$, and $>79 \%$ for $\mathrm{Cd}$ ). $\mathrm{DCd}$ showed strong correlations with phosphate and silicate $(r=0.88-0.89)$. The correlations for DNi and DCu with phosphate and silicate were moderate $(r=0.66-0.77) . \mathrm{DNi}, \mathrm{DCu}$ and $\mathrm{DCd}$ were 
1 strongly correlated with each other $(r=0.85-0.90)$. The concentration of TDNi in deep

2 water was similar to that observed in the eastern Arctic Ocean (3.7-3.9 $\mathrm{nmol} \mathrm{kg}^{-1}$ ) (Mart et al.

3 1984). The profiles of DCu and DCd accorded with those observed at LOREX station

4 (Moore 1981). Although TDZn was also dominated by dissolved species ( $>75 \%)$, it showed

5 a vertical profile distinct from the other trace metals. It was characterized by broad

6 maximums in shallow $(<150 \mathrm{~m})$ and middle $(1250-1500 \mathrm{~m})$ depths. The reason for the

7 decoupling between $\mathrm{Zn}$ and nutrients is not clear now. The concentration of DZn at A023

8 was similar to that at LOREX station (Moore 1981). TDPb and DPb were generally low

9 throughout the water column. The relatively high variations might have been caused by

10 problems in sampling and/or analysis. The concentrations of TDPb were within the range of

$11 \quad 15-72 \mathrm{pmol} \mathrm{kg}^{-1}$ reported for the eastern Arctic Ocean (Mart et al. 1984).

4. Discussion

4.1. Regional variation of bioactive trace metals

The ranges of the TDM concentration at each station are plotted in Fig. 9. The average TDM/DM ratio at each station is plotted in Fig. 10. It is obvious that there are considerable variations in the concentrations of TDMs in the study area. Particularly, TDAl, TDMn, TDFe, TDCo and TDPb showed wide variations. The average TDM/DM ratios of these metals were generally high and also showed considerable spatial variations: 1.6-414 for Al, 1.8-28 for $\mathrm{Mn}, 29-873$ for $\mathrm{Fe}, 1.4-2.2$ for $\mathrm{Co}$ and 1.1-4.8 for $\mathrm{Pb}$. These results indicate that substantial amounts of these metals are supplied from localized sources and that species of the input are mostly in a labile particulate fraction, such as terrigenous clay minerals, and/or transformed promptly into labile particulate species, such as authigenic Fe-Mn oxides. The major local sources are the Pacific water that flows through the Bering Strait (A001, Fig. 
1 (A018, Fig. 5), as described in the results section. Most of the input is removed from

2 seawater within the shelf and slope regions, resulting in low concentrations at a pelagic

3 station A023 (Fig. 7). Such removal is consistent with that described in literature for Fe

4 (Klunder et al. 2012a; Nakayama et al. 2011; Thuróczy et al. 2011), for Mn (Middag et al.

5 2011) and for ${ }^{210} \mathrm{~Pb}$ (Lepore et al. 2009). TDNi, TDCu and TDZn also gave relatively high

6 concentrations at A001, A002 and A018, suggesting the importance of input from the Bering

7 Strait and the Mackenzie River (Figs. 3, 5 and 9). The effect of local sources was not clear

8 for TDCd. It is probable that the distribution of $\mathrm{Cd}$ is primarily controlled by uptake and

9 remineralization through the biogeochemical cycle. The correlation between $\mathrm{Cd}$ and

10 nutrients will be discussed in the section 4.3. The TDM/DM ratio for $\mathrm{Ni}, \mathrm{Cu}, \mathrm{Zn}$ and $\mathrm{Cd}$

11 were close to 1 except at A001, A002 and A018 (Fig. 10). Thus, Ni, Cu, Zn and Cd are

12 dominated by dissolved species in this area. Especially, DCd represented $95 \%$ of TDCd in

13 average. This result is clearly different from the observations on the Bering Sea shelf, where

14 the labile particulate fraction accounts for $20-80 \%$ of TDNi, TDCu, TDZn and TDCd (Cid et

15 al. 2011). This is probably due to the high concentrations of TDFe $(3500 \mathrm{nmol} / \mathrm{kg}$ in 16 average $)$ and TDMn (80 nmol/kg in average) and the adsorption of trace metals on Fe-Mn oxides in the Bering Sea.

4.2. Input of bioactive trace metals from the Bering Strait and the Mackenzie River

Among the three sources mentioned above, the Pacific inflow water and the

21 Mackenzie River water carry new import of bioactive trace metals to the study area. Here we estimate amounts of their annual input. The concentration of TDMs in the Pacific inflow water can be expressed by the average concentration at A001. The water inflow is estimated to be $25,000 \mathrm{~km}^{3} \mathrm{y}^{-1}$ (Woodgate and Aagaard 2005). To evaluate the concentration of TDMs in the Mackenzie River water, we can use linear regression between TDM and S at 
1 A018. Good linearity was observed for each TDM $\left(R^{2}>0.90\right)$ except $\operatorname{TDCd}\left(R^{2}=0.18\right)$.

2 Annual water discharge is assumed to be $290 \mathrm{~km}^{3} \mathrm{y}^{-1}$ for the Mackenzie River (Dittmar and

3 Kattner 2003). The resulting concentration and annual input of TDMs for the Pacific inflow

4 water and the Mackenzie River water are summarized in Table 2. The TDM concentration is

5 higher in the Mackenzie River water than in the Pacific inflow water by a factor of 1.2-7.3.

6 However, the annual input from the Mackenzie River is only 1-8\% of that from the Bering

7 Strait. The figures in Table 2 are just a first approximation, since it is based on only single

8 observation in summer. In the Lena River (Arctic Siberia), significantly high concentrations

9 of DMs were observed during the spring high flow (Hölemann et al. 2005). It seems likely

10 that there would be a similar seasonal variation in the Mackenzie River. In addition, we do

11 not know the seasonal change in concentration of trace metals in the Pacific inflow water.

12 We think, however, these figures may be useful, since they are the first estimation of annual input of TDMs by the Pacific inflow water and the Mackenzie River water.

\subsection{Stoichiometry of bioactive trace metals}

Here we examine the relationship among bioactive trace metals and oceanographic parameters over the study area. Correlation matrixes for TDMs, DMs and LPMs for all samples are given in Appendix Tables 2-4. TDNi and TDCu showed the highest correlation coefficient among TDMs $(r=0.93, n=136)$. DNi and DCu also showed the highest correlation coefficient among DMs for all samples $(r=0.84)$. TDNi, TDCu, TDZn and

21 TDAl showed moderate to strong correlations with each other $(r=0.69-0.93)$. LPNi and

22 LPZn also showed moderate correlations with LPAl $(r=0.68-0.79)$. Ni, $\mathrm{Cu}$ and $\mathrm{Zn}$ did not 23 show significant correlations with nutrients and Chl. $a$. A remarkably high linearity was 24 observed between TDCu and TDNi for stations except those near the Bering Strait, where TDCu was relatively elevated (Fig 11a): 


$$
R^{2}=0.95, n=126
$$

2 A similar high linearity was observed on the Bering Sea shelf with a higher slope (Cid et al. 3 2011):

$$
R^{2}=0.97, n=44
$$

These results suggest dominant effect of physical transport and chemical reactions, such as

6 redox and scavenging, on the distribution of $\mathrm{Ni}, \mathrm{Cu}$ and $\mathrm{Zn}$ in these areas (Figs. 3-7). It is

7 likely that differentiation between $\mathrm{Ni}$ and $\mathrm{Cu}$ was weak, because biogeochemical cycling was less important in controlling the distribution.

In contrast, DCd showed moderate correlations with phosphate $(r=0.79)$ and silicate $(r=0.77)$. A regression line between DCd and phosphate was calculated for all samples as follows (Fig 11b):

$$
\left[\mathrm{DCd} \mathrm{nmol} \mathrm{kg}{ }^{-1}\right]=0.33\left[\mathrm{PO}_{4} \mu \mathrm{mol} \mathrm{kg}{ }^{-1}\right]+0.050
$$$$
R^{2}=0.62, n=134
$$

The slope was significantly higher than that of the regression line observed on the Bering Sea shelf (Cid et al. 2011):

$$
\left[\mathrm{DCd} \mathrm{nmol} \mathrm{kg}{ }^{-1}\right]=0.19\left[\mathrm{PO}_{4} \mu \mathrm{mol} \mathrm{kg}{ }^{-1}\right]+0.185 \quad R^{2}=0.74, n=43
$$

Cullen (2006) proposed that preferential uptake of DCd in Fe-limited surface water would cause a kink in the DCd-P relationship. Our results are consistent with this model: these areas were Fe-sufficient and there were no kinks in the DCd-P relationship. DIN is plotted against DCd in Fig. 11c. There are two different trends in this figure for low salinity SW and for high salinity AIW and CBDW. These characteristics are similar to those observed between nitrate and phosphate (Jones et al. 1998) or between DIN and phosphate (Yamamoto-Kawai et al. 2008). The two trends between nitrogen vs. phosphorus were attributed to different origins, namely Pacific and Atlantic waters. The two trends between DIN and DCd may be explained similarly. The regression line is as follows for SW within the range of $30<\mathrm{S}<33$ : 


$$
R^{2}=0.50, n=63
$$

2 Although it is difficult to establish a regression line for AIW and CBDW because of 3 insufficient data, the slope looks like higher than observed in SW, similar to the 4 nitrogen-phosphorus relationship (Jones et al. 1998; Yamamoto-Kawai et al. 2008). The 5 following regression was observed on the Bering Sea shelf (Cid et al. 2011):

$$
R^{2}=0.69, n=43
$$

These results suggest that DCd behaves similarly with phosphate in this area as well as in the other oceanic regimes (Cullen 2006; de Baar et al. 1994). It is likely that biogeochemical cycling is an important factor controlling the distribution of $\mathrm{Cd}$. The stoichiometry between $\mathrm{Cd}$ and nutrients, however, is distinct between the Arctic Ocean and the Bering Sea. Moderate correlations occurred among TDFe, TDCo and TDAl $(r=0.70-0.85)$. Moderate correlations were also found among DMn, DFe, DCo and ammonium $(r=$ 0.63-0.78). Although DFe shows positive correlations with nutrients in the oceans (Johnson et al. 1997; Turner and Hunter 2001), there were no significant correlations between DFe and nutrients in this area. DCo is plotted against DMn in Fig. 11d. In this case, there is difference in stoichiometry between the Chukchi shelf and pelagic stations. The regression line for A009 is as follows:

$$
R^{2}=0.97, n=11
$$

The regression line for A023 is as follows:

$$
[\text { DCo pmol kg-1 }]=91\left[\mathrm{DMn} \mathrm{nmol} \mathrm{kg}{ }^{-1}\right]+28
$$

$$
R^{2}=0.69, n=23
$$

In the other oceans, DCo takes different distribution from DMn due to biological uptake and remineralization from settling particles in depth in addition to scavenging (Noble et al. 2008). It is likely that biological uptake and remineralization are less significant for Co in the Arctic Ocean, resulting in the strong correlations with $\mathrm{Mn}$. The former regression should be attributed to reductive dissolution-oxidative removal in the shelf and slope area (Appendix 
1 Figs. 2 and 4), and the latter regression should be attributed to scavenging in CBDW (Fig. 7),

2 which has a mean age of about 450 years (Talley et al. 2011). Similarly the biogeochemical 3 cycling has only minor effect on the distribution of Fe.

For all samples, LPPb showed weak correlations with LPFe $(r=0.66)$ and LPCo $(r$

$5=0.60$ ), while $\mathrm{TDPb}$ and $\mathrm{DPb}$ did not show a significant correlation with the other parameters.

6 This may be ascribed to the effect of aeolian supply of anthropogenic $\mathrm{Pb}$.

The average composition of four water masses, UHL, LHL, AIW and CBDW, is summarized in Table 3. TDAl, TDPb, and DPb in CBDW were removed from the following

9 discussion due to the above-mentioned problems on data quality. SW was not included here,

10 because its salinity and concentrations of constituents varied substantially. Using these data,

11 we have calculated the $\mathrm{DM} / \mathrm{P}$ and nutrient/P ratio for each water mass and compared the

12 results with that for North Pacific deep water and Bering Sea water (Fig. 12). The ratio for

13 the North Pacific deep water was calculated using our unpublished data. The ratio for the

14 Bering Sea water was calculated using data for BR013 (Cid et al. 2011), which was almost

15 identical with that for A001. It is apparent that the variation of $\mathrm{DM} / \mathrm{P}$ is distinct from $\mathrm{Si} / \mathrm{P}$

16 and DIN/P. The Bering Sea water is enriched with trace metals especially with Al, Mn, Fe,

$17 \mathrm{Co}$ and $\mathrm{Pb}$ compared to the Pacific water. Generally $\mathrm{DAl} / \mathrm{P}, \mathrm{DMn} / \mathrm{P}, \mathrm{DCo} / \mathrm{P}$ and $\mathrm{DFe} / \mathrm{P}$ in the Arctic waters are between the ratios for the Bering and Pacific waters. DAl/P and $\mathrm{DMn} / \mathrm{P}$ vary substantially among the water masses in the Arctic Ocean. DNi/P, DCu/P,

$\mathrm{DZn} / \mathrm{P}$ and $\mathrm{DCd} / \mathrm{P}$ in the Arctic waters are comparable to those in the Pacific water, whereas

$21 \mathrm{DPb} / \mathrm{P}$ in the Arctic waters is close to that in the Bering water. The dissolved elemental ratio is $\mathrm{P}: \mathrm{Al}: \mathrm{Mn}: \mathrm{Fe}: \mathrm{Co}: \mathrm{Ni}: \mathrm{Cu}: \mathrm{Zn}: \mathrm{Cd}=1: 1.2 \times 10^{-2}: 4.4 \times 10^{-4}: 1.4 \times 10^{-3}: 3.7 \times 10^{-5}:$ $3.7 \times 10^{-3}: 1.4 \times 10^{-3}: 4.5 \times 10^{-3}: 2.2 \times 10^{-4}$ for CBDW. This ratio is significantly different 24 from that for the Pacific and Bering waters. Bruland et al. (1991) proposed an approximate 
$1 \mathrm{Cd}=1: 0.005: 0.002: 0.0004$. Compared to this requirement, $\mathrm{CBDW}$ is poor in $\mathrm{DFe}$ and

2 DCd. According to Twining et al. (2011), Fe : Co ratio was 10-100: 1 in plankton. Thus,

3 DCo could be also insufficient, when macro- and micro-nutrients in CBDW are utilized by

4 phytoplankton according to the reported stoichiometry.

$6 \quad 5$. Conclusions

The trace metal composition of Pacific inflow water through the Bering Strait is considerably different from that of Pacific deep water. The composition is further modified

9 in the Chukchi and Beaufort Seas. Reductive sediments on the shelf or slope and the

10 Mackenzie River supply a large amount of $\mathrm{Al}, \mathrm{Mn}, \mathrm{Fe}$ and $\mathrm{Co}$, resulting in high loads of

11 labile particulate species in seawater. Although correlation between DCd and phosphate is 12 consistent with the other oceans, this area is unique in weak or insignificant correlations 13 between the other DMs and nutrients. Some behaviors of trace metals are also unique in this 14 area: remarkable correlations between TDNi and TDCu or between DCo and DMn, and 15 decoupling of DZn from nutrients. These results suggest that biogeochemical cycling is not 16 a dominant factor controlling the distribution of trace metals in this area. Probably physical 17 transport and chemical reactions, such as redox and scavenging, are more important. Further study is necessary to quantify the mechanism controlling the distribution of trace metals.

Acknowledgements

A.P.C. was supported by Monbukagakusho (MEXT) scholarship. We are grateful to Captain Masaharu Akamine and the crew of R/V Mirai (JAMSTEC) during the MR00-K06 cruise. We thank the chief scientist Dr. Takatoshi Takizawa, Prof. Noriyuki Tanaka, and onboard scientists and technicians. Basic oceanographic parameters were obtained thanks to staffs from JAMSTEC and Nippon Marine Enterprises. This research was partly supported 
1 by funds from the Steel Industry Foundation for the Advancement of Environmental

2 Protection Technology and from Grant-in-Aid of Scientific Research, the Ministry of 3 Education, Culture, Sports, Science, and Technology of Japan.

4

5 
$1 \quad$ Figure captions

2 Figure 1. Sampling locations in the western Arctic Ocean. Schematics of water masses

3 and currents are also shown using arrows: dark blue, Alaska Coastal Water (ACW); purple,

4 Bering Shelf-Anadyr Water (BSAW); pale blue, Siberian Coastal Current; yellow, Atlantic

5 Intermediate Water (AIW, subsurface); red, Beaufort Gyre (surface).

6 Figure 2. Potential temperature-salinity diagram: $\bigcirc$, A001; $\boldsymbol{\ominus}, \mathrm{A} 002 ; \square, \mathrm{A} 003 ; \mathbf{\square}, \mathrm{A} 005$;

$7 \diamond, \mathrm{A} 009 ; \diamond, \mathrm{A} 016 ; \triangle, \mathrm{A} 022 ; \boldsymbol{\Delta}, \mathrm{A} 023 ;$ ¡ $\mathrm{A} 039 ; \times, \mathrm{A} 042 ; \boldsymbol{\Lambda}, \mathrm{A} 054$.

8 Figure 3. Vertical distributions of TDMs at A001 (๑), A002 $(\bullet)$ and BR013 $\left(167^{\circ} \mathrm{W}\right.$, $9 \quad 64.0^{\circ} \mathrm{N} ; \triangle$ ) in the northern Bering Sea (Cid et al. 2011).

10 Figure 4. Sectional distributions of TDMs and potential temperature in the Barrow Canyon.

11 Figure 5. Sectional distributions of TDMs and salinity in the Mackenzie Trough.

12 Figure 6. Vertical profiles of TDMs on the slope of the Beaufort Sea: $\bigcirc$, A054; $\mathbf{\square}, \mathrm{A} 003$; $13 \diamond, \mathrm{A} 016 ; \boldsymbol{\Delta}, \mathrm{A} 022$

14 Figure 7. Vertical profiles of TDMs $(\bigcirc)$ and DMs $(0)$ at A023.

15 Figure 8. Plot of DAl versus silicate at A023: $\bigcirc$, upper water $(<300 \mathrm{~m})$; $\bigcirc$, intermediate 16 water $(500-1750 \mathrm{~m})$; $\square$, deep water $(>2000 \mathrm{~m})$. The formulas of regression lines are 17 presented in the text.

18 Figure 9. Concentration ranges of TDMs at each station. The top and bottom bars 19 represent the maximum and minimum vales, respectively.

20 Figure 10. Variations in the average TDM/DM ratio at each station: $\bigcirc, \mathrm{Al} ; \square, \mathrm{Mn} ; \diamond, \mathrm{Fe}$; $21 \triangle, \mathrm{Co} ; \boldsymbol{\bullet}, \mathrm{Zn} ; \mathbf{\square}, \mathrm{Cd} ; \diamond, \mathrm{Pb}$.

22 Figure 11. (a) TDCu vs. TDNi. The red line presents the regression line for stations except 23 A01 and A02. (b) DCd vs. phosphate. The red line presents the regression line for all 24 samples. (c) DIN vs. DCd. The red line presents the regression line for SW $(30<\mathrm{S}<33)$ and the blue broken line presents a speculated relationship for Atlantic water.

(d) DCo vs. 
1 DMn. The red and blue lines present the regression lines for A009 and A023, respectively.

2 The color of the dots represents salinity. The formulas of regression lines are presented in the 3 text.

4 Figure 12. The average DM/P and nutrient/P ratio of each water mass: $\bigcirc$, UHL; $\bigcirc$, LHL; $5 \quad \square$, AIW; $\mathbf{\square}$, CBDW; $\triangle$, Bering Sea; $\boldsymbol{\Lambda}$, North Pacific Deep Water.

6

7

8

9

10

11

12

13 14 Mackenzie Trough.

15

16

17

18

19

20 Barrow Canyon.

Appendix Figure captions

Appendix Figure 1. Vertical distributions of DMs and oceanographic parameters at A001 $(\bullet), A 002(\diamond)$ and BR013 $\left(167^{\circ} \mathrm{W}, 64.0^{\circ} \mathrm{N} ; \triangle\right)$ in the northern Bering Sea (Cid et al. 2011).

Appendix Figure 2. Sectional distributions of DMs and oceanographic parameters in the

Appendix Figure 3. Sectional distributions of DMs and oceanographic parameters in the

5 Appendix Figure 4. Vertical profiles of DMs and oceanographic parameters on the slope of 6 the Beaufort Sea: $\bigcirc$, A054; $\mathbf{\square}, \mathrm{A} 003 ; \diamond, \mathrm{A} 016 ; \boldsymbol{\Delta}, \mathrm{A} 022$.

7 Appendix Figure 5. Vertical profiles of oceanographic parameters at A023. 
1 References

2 Aagaard K, Coachman LK, Carmack E (1981) On the halocline of the Arctic Ocean. Deep-Sea Res A 28: 529-545. doi: 10.1016/0198-0149(81)90115-1

Bruland KW, Donat JR, Hutchins DA (1991) Interactive influences of bioactive trace metals on biological production in oceanic waters. Limnol Oceanogr 36: 1555-1577.

Cid AP, Urushihara S, Minami T, Norisuye K, Sohrin Y (2011) Stoichiometry among bioactive trace metals in seawater on the Bering Sea shelf. J Oceanogr 67: 747-764. doi: $10.1007 / \mathrm{s} 10872-011-0070-\mathrm{Z}$

Codispoti LA, Flagg C, Kelly V, Swift JH (2005) Hydrographic conditions during the 2002 SBI process experiments. Deep-Sea Res II 52: 3199-3226. doi: 10.1016/j.dsr2.2005.10.007

Cullen JT (2006) On the nonlinear relationship between dissolved cadmium and phosphate in the modern global ocean: Could chronic iron limitation of phytoplankton growth cause the kink? Limnol Oceanogr 51: 1369-1380.

Danielson L-G, Westerlund S (1983) Trace metals in the Arctic Ocean. In: Wong CS, Boyle EA, Bruland KW, Burton JD, Goldberg ED (eds) Trace Metals in Sea Water, Wiley, New York, pp. 85-95.

de Baar HJW, Saager PM, Nolting RF, van der Meer J (1994) Cadmium versus phosphate in the world ocean. Mar Chem 46: 261-281. doi: 10.1016/0304-4203(94)90082-5

Dittmar T, Kattner G (2003) The biogeochemistry of the river and shelf ecosystem of the Arctic Ocean: a review. Mar Chem 83: 103-120. doi: 10.1016/s0304-4203(03)00105-1

Ezoe M, Ishita T, Kinugasa M, Lai X, Norisuye K, Sohrin Y (2004) Distributions of dissolved and acid-dissolvable bioactive trace metals in the North Pacific. Geochem J 38: $535-550$.

Grebmeier JM, Cooper LW, Feder HM, Sirenko BI (2006) Ecosystem dynamics of the 
Pacific-influenced Northern Bering and Chukchi Seas in the Amerasian Arctic. Progr Oceanogr 71: 331-361.

Hölemann JA, Schirmacher M, Prange A (2005) Seasonal variability of trace metals in the Lena River and the southeastern Laptev Sea: Impact of the spring freshet. Global and Planetary Change 48: 112-125. doi: 10.1016/j.gloplacha.2004.12.008

Johnson KS, Gordon RM, Coale KH (1997) What controls dissolved iron concentrations in the world ocean? Mar Chem 57: 137-161. doi: 10.1016/s0304-4203(97)00043-1

Jones EP, Rudels B, Anderson LG (1995) Deep waters of the Arctic Ocean: origins and circulation. Deep-Sea Res I 42: 737-760. doi: 10.1016/0967-0637(95)00013-v

Jones EP, Anderson LG, Swift JH (1998) Distribution of Atlantic and Pacific waters in the upper Arctic Ocean: Implications for circulation. Geophys Res Lett 25: 765-768. doi: $10.1029 / 98 \mathrm{~g} 100464$

Klunder MB, Bauch D, Laan P, de Baar HJW, van Heuven S, Ober S (2012a) Dissolved iron in the Arctic shelf seas and surface waters of the central Arctic Ocean: Impact of Arctic river water and ice-melt. J Geophys Res 117: C01027. doi: $10.1029 / 2011 \mathrm{jc} 007133$

Klunder MB, Laan P, Middag R, de Baar HJW, Bakker K (2012b) Dissolved iron in the Arctic Ocean: Important role of hydrothermal sources, shelf input and scavenging removal. J Geophys Res 117: C04014. doi: 10.1029/2011jc007135

Lepore K, Moran SB, Smith JN (2009) ${ }^{210} \mathrm{~Pb}$ as a tracer of shelf-basin transport and sediment focusing in the Chukchi Sea. Deep-Sea Res II 56: 1305-1315. doi: 10.1016/j.dsr2.2008.10.021

Mart L, Nürnberg HW, Dyrssen D (1984) Trace metal levels in the Eastern Arctic Ocean. Sci Total Environ 39: 1-14. doi: 10.1016/0048-9697(84)90020-2

Measures CI (1999) The role of entrained sediments in sea ice in the distribution of 
aluminium and iron in the surface waters of the Arctic Ocean. Mar Chem 68: 59-70. doi: 10.1016/s0304-4203(99)00065-1

Middag R, de Baar HJW, Laan P, Bakker K (2009) Dissolved aluminium and the silicon cycle in the Arctic Ocean. Mar Chem 115: 176-195. doi: 10.1016/j.marchem.2009.08.002

Middag R, de Baar HJW, Laan P, Klunder MB (2011) Fluvial and hydrothermal input of manganese into the Arctic Ocean. Geochim Cosmochim Acta 75: 2393-2408. doi: 10.1016/j.gca.2011.02.011

Moore RM (1981) Oceanographic distributions of zinc, cadmium, copper and aluminium in waters of the central arctic. Geochim Cosmochim Acta 45: 2475-2482. doi: $10.1016 / 0016-7037(81) 90099-5$

Moore RM (1983) The relationship between distributions of dissolved cadmium, iron and aluminum and hydrography in the central Arctic Ocean. In: Wong CS, Boyle EA, Bruland KW, Burton JD, Goldberg ED (eds) Trace Metals in Sea Water, Wiley, New York, pp. 131-142.

Nakayama Y, Fujita S, Kuma K, Shimada K (2011) Iron and humic-type fluorescent dissolved organic matter in the Chukchi Sea and Canada Basin of the western Arctic Ocean. J Geophys Res 116: C07031. doi: 10.1029/2010jc006779

Noble AE, Saito MA, Maiti K, Benitez-Nelson CR (2008) Cobalt, manganese, and iron near the Hawaiian Islands: A potential concentrating mechanism for cobalt within a cyclonic eddy and implications for the hybrid-type trace metals. Deep-Sea Res II 55: 1473-1490.

Participants of MR00-K06, 2000. R/V Mirai MR00-K06 Cruise Report. Japan Marine Science and Technology Center.

SCOR Working Group (2007) GEOTRACES - An international study of the global marine 
biogeochemical cycles of trace elements and their isotopes. Chemie der Erde Geochemistry 67: 85-131.

Sohrin Y, Urushihara S, Nakatsuka S, Kono T, Higo E, Minami T, Norisuye K, Umetani S (2008) Multielemental determination of GEOTRACES key trace metals in seawater by ICPMS after preconcentration using an ethylenediaminetriacetic acid chelating resin. Anal Chem 80: 6267-6273.

Sohrin Y, Bruland KW (2011) Global status of trace elements in the ocean. Trends Anal Chem 30: 1291-1307. doi: 10.1016/j.trac.2011.03.006

Swift JH, Jones EP, Aagaard K, Carmack EC, Hingston M, MacDonald RW, McLaughlin FA, Perkin RG (1997) Waters of the Makarov and Canada basins. Deep-Sea Res II 44: 1503-1529. doi: 10.1016/s0967-0645(97)00055-6

Talley LD, Pickard GL, Emery WJ, Swift JH (2011) Descriptive Physical Oceanography: An Introduction. Elsevier, Amsterdam.

Thuróczy CE, Gerringa LJA, Klunder M, Laan P, Le Guitton M, de Baar HJW (2011) Distinct trends in the speciation of iron between the shallow shelf seas and the deep basins of the Arctic Ocean. J Geophys Res 116: C10009. doi: 10.1029/2010jc006835

Turner DR, Hunter KA (2001) The Biogeochemistry of Iron in Seawater. John Wiley \& Sons, Chichester.

Twining BS, Baines SB, Bozard JB, Vogt S, Walker EA, Nelson DM (2011) Metal quotas of plankton in the equatorial Pacific Ocean. Deep-Sea Res II 58: 325-341. doi: 10.1016/j.dsr2.2010.08.018

Wang D, Henrichs SM, Guo L (2006) Distributions of nutrients, dissolved organic carbon and carbohydrates in the western Arctic Ocean. Cont Shelf Res 26: 1654-1667. doi: 10.1016/j.csr.2006.05.001

Woodgate RA, Aagaard K (2005) Revising the Bering Strait freshwater flux into the Arctic 
2 Yamamoto-Kawai M, McLaughlin FA, Carmack EC, Nishino S, Shimada K (2008) Freshwater budget of the Canada Basin, Arctic Ocean, from salinity, d18O, and nutrients. J Geophys Res 113: C01007. doi: 10.1029/2006jc003858

5 Yeats PA (1988) Manganese, nickel, zinc and cadmium distributions at the Fram 3 and Cesar $6 \quad$ ice camps in the Arctic Ocean. Oceanologica Acta 11: 383-388.

7 Yeats PA, Westerlund S (1991) Trace metal distributions at an Arctic Ocean ice island. Mar 8 Chem 33: 261-277. doi: 10.1016/0304-4203(91)90071-4

9 


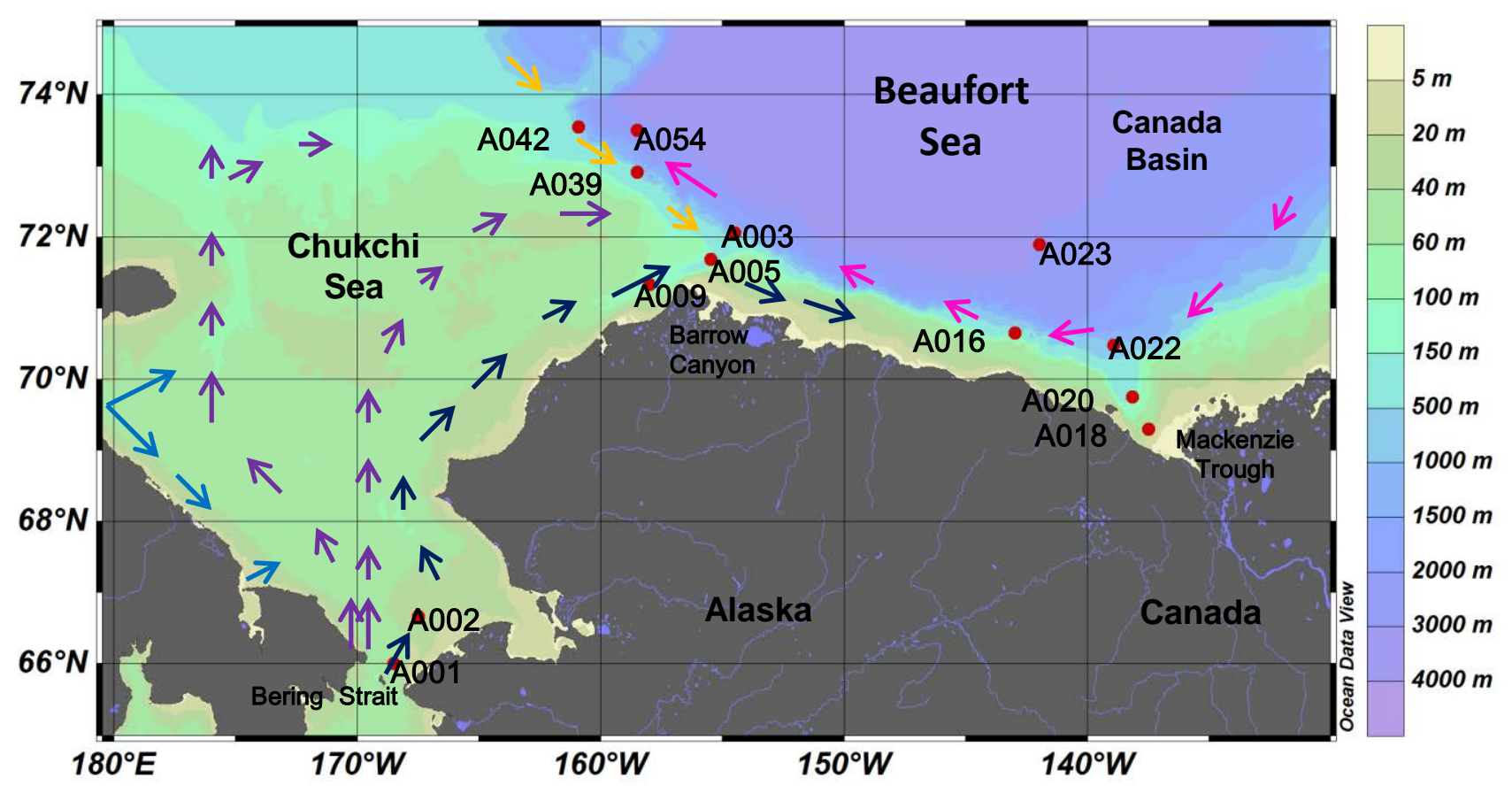

Figure 1 


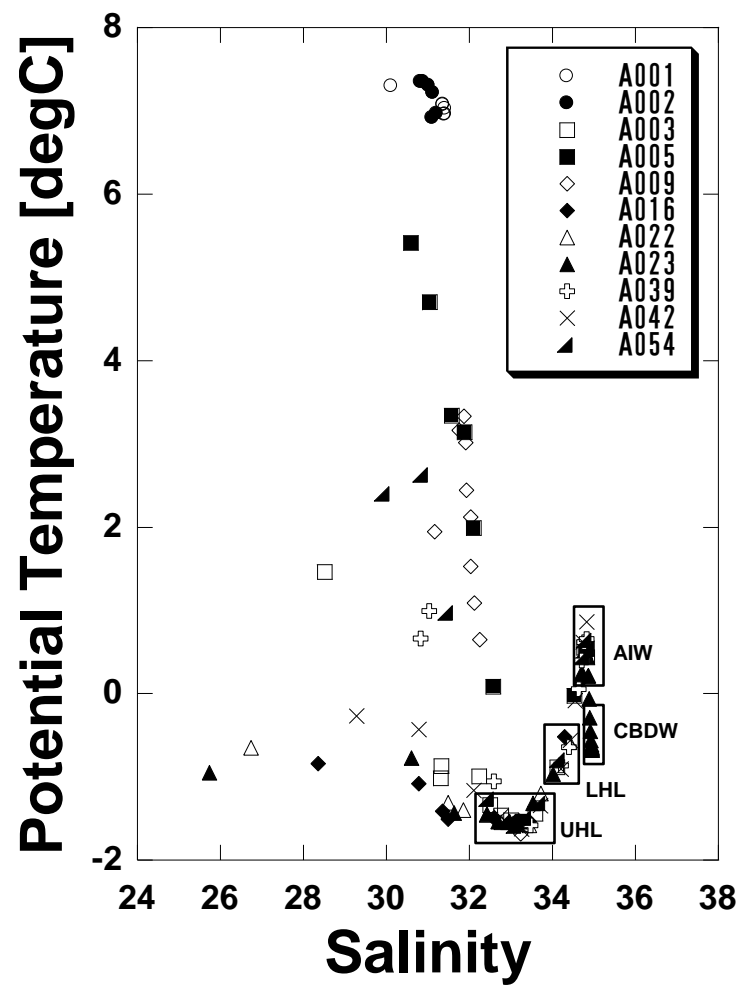

Figure 2 

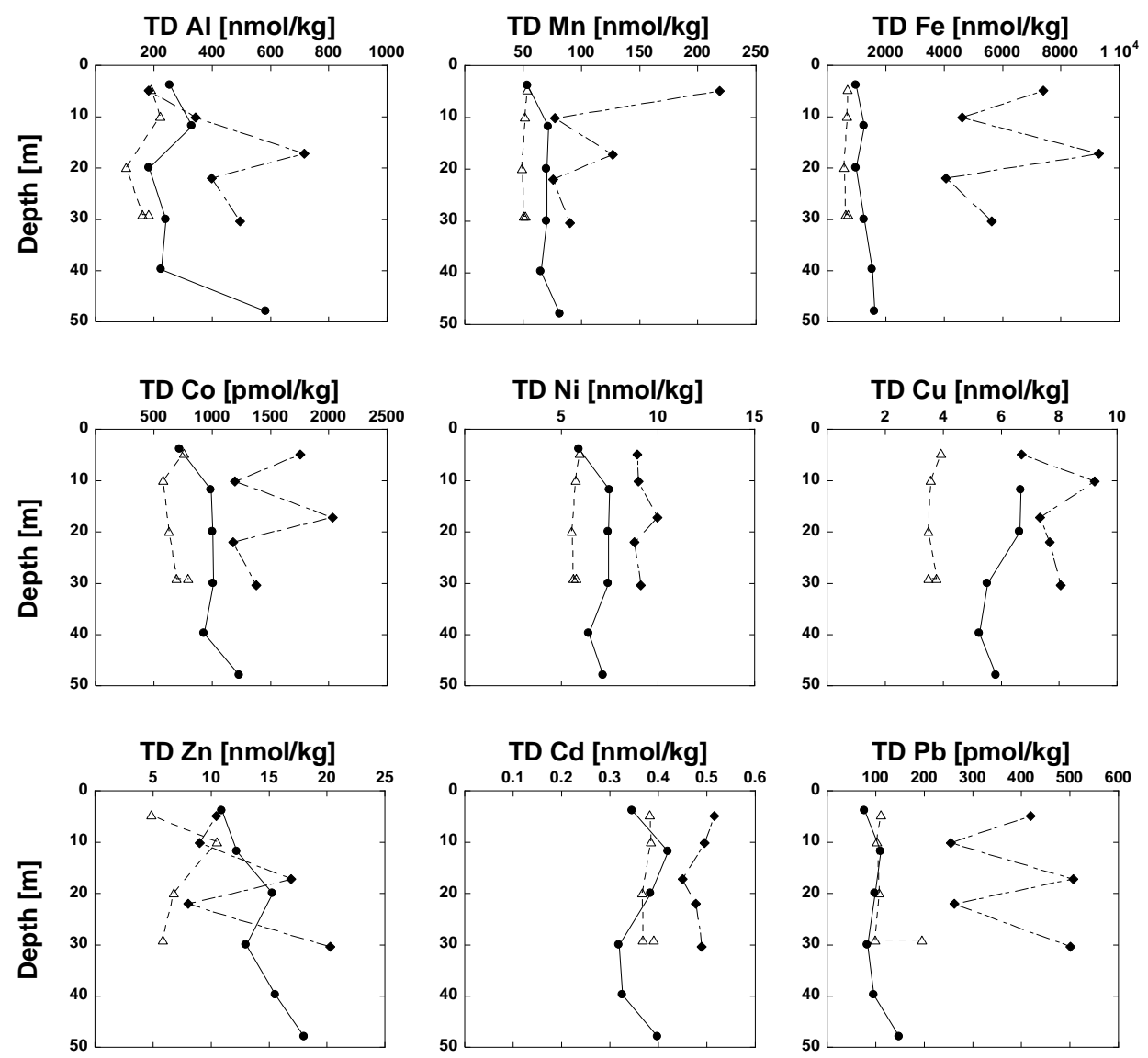

Figure 3 
TD Al [nmol/kg]

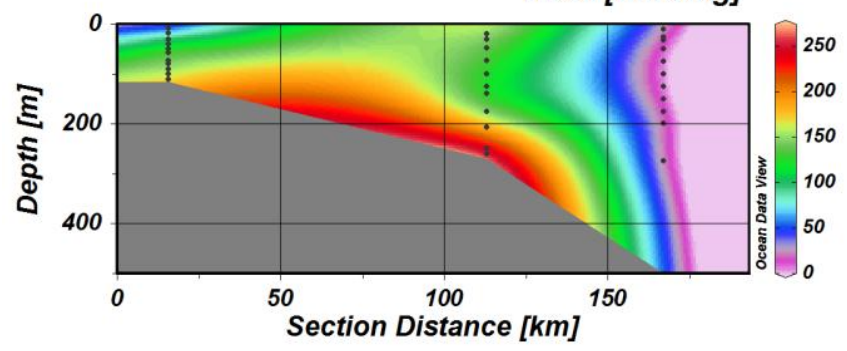

TD Fe [nmol/kg]

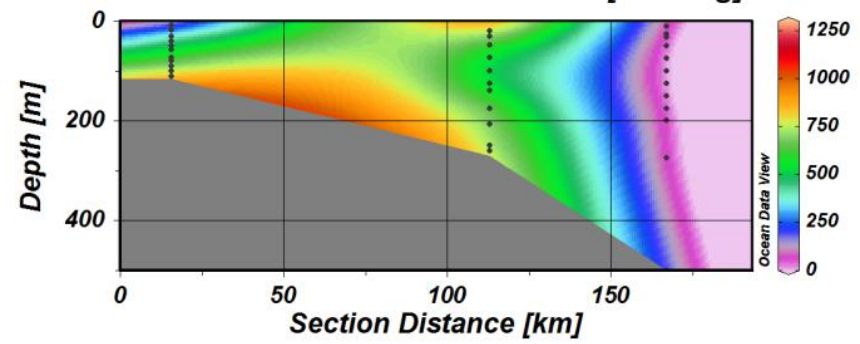

TD Ni [nmol/kg]

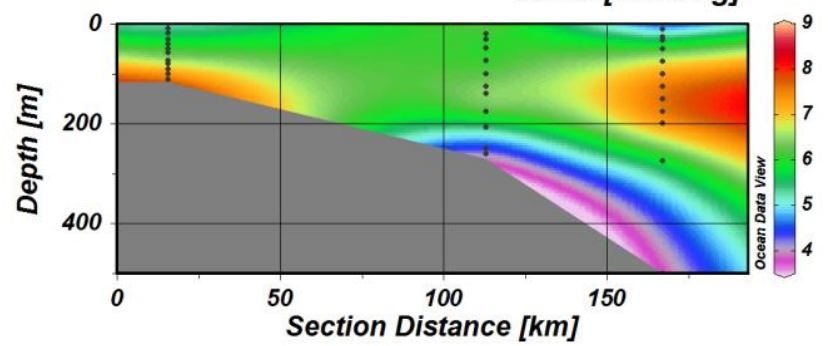

TD Zn [nmol/kg]

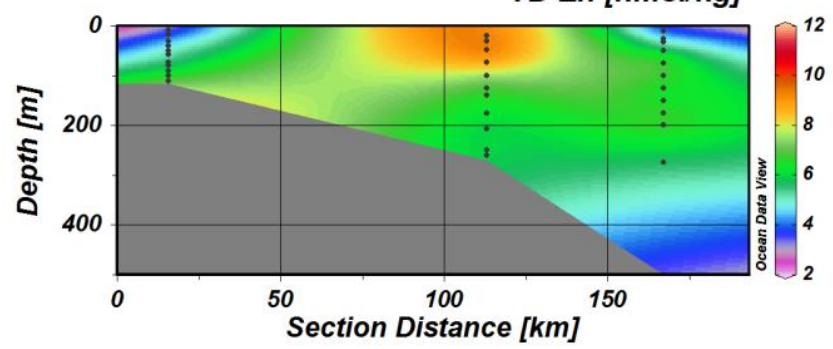

$\mathrm{TD} \mathrm{Pb}[\mathrm{pmol} / \mathrm{kg}]$

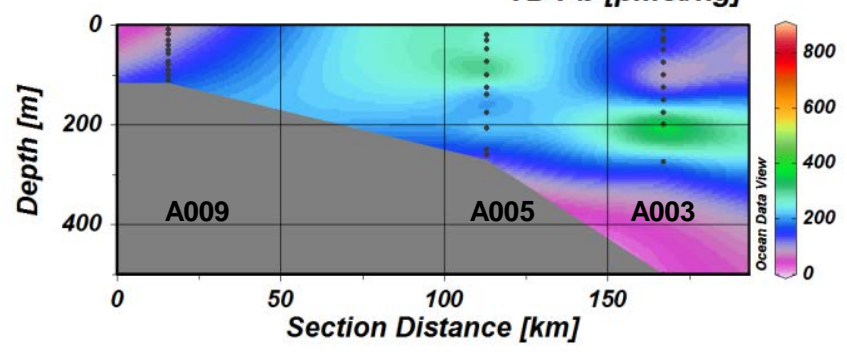

TD Mn [nmol/kg]

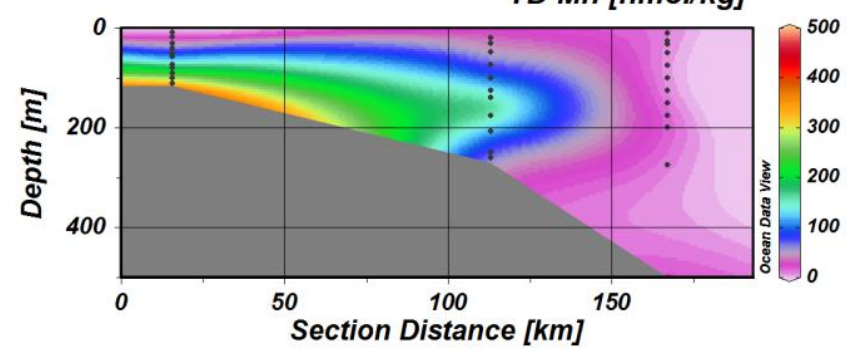

TD Co [pmol/kg]

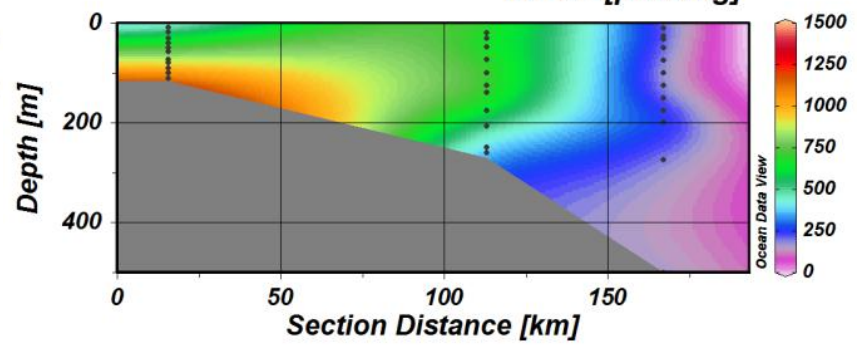

TD Cu [nmol/kg]
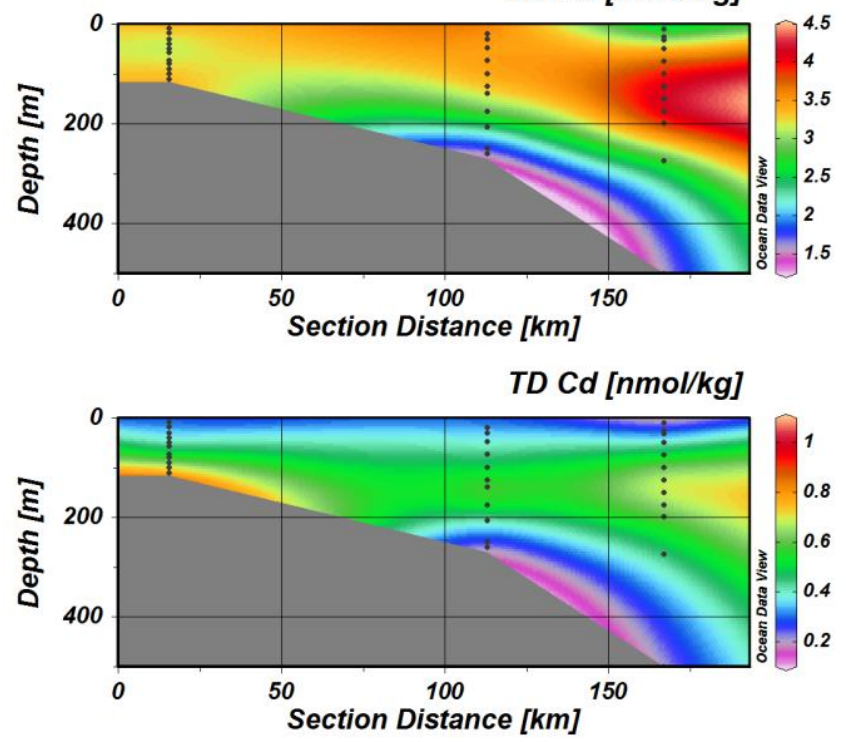

Potential Temperature $\theta$ [degC]

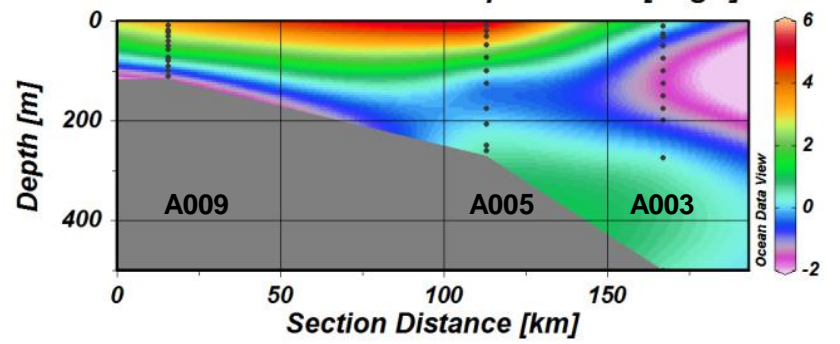



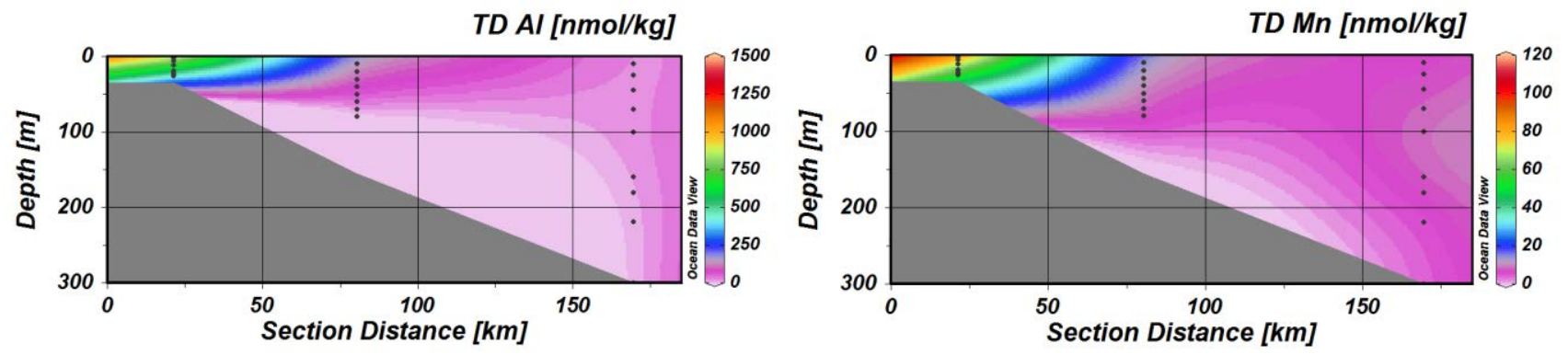

TD Fe [nmol/kg]
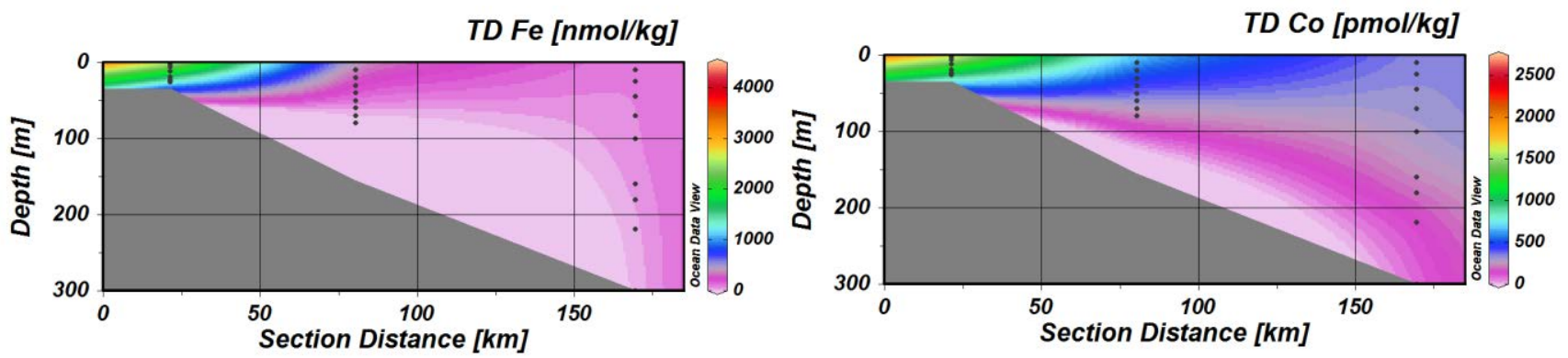

TD Ni $[\mathrm{nmol} / \mathrm{kg}]$
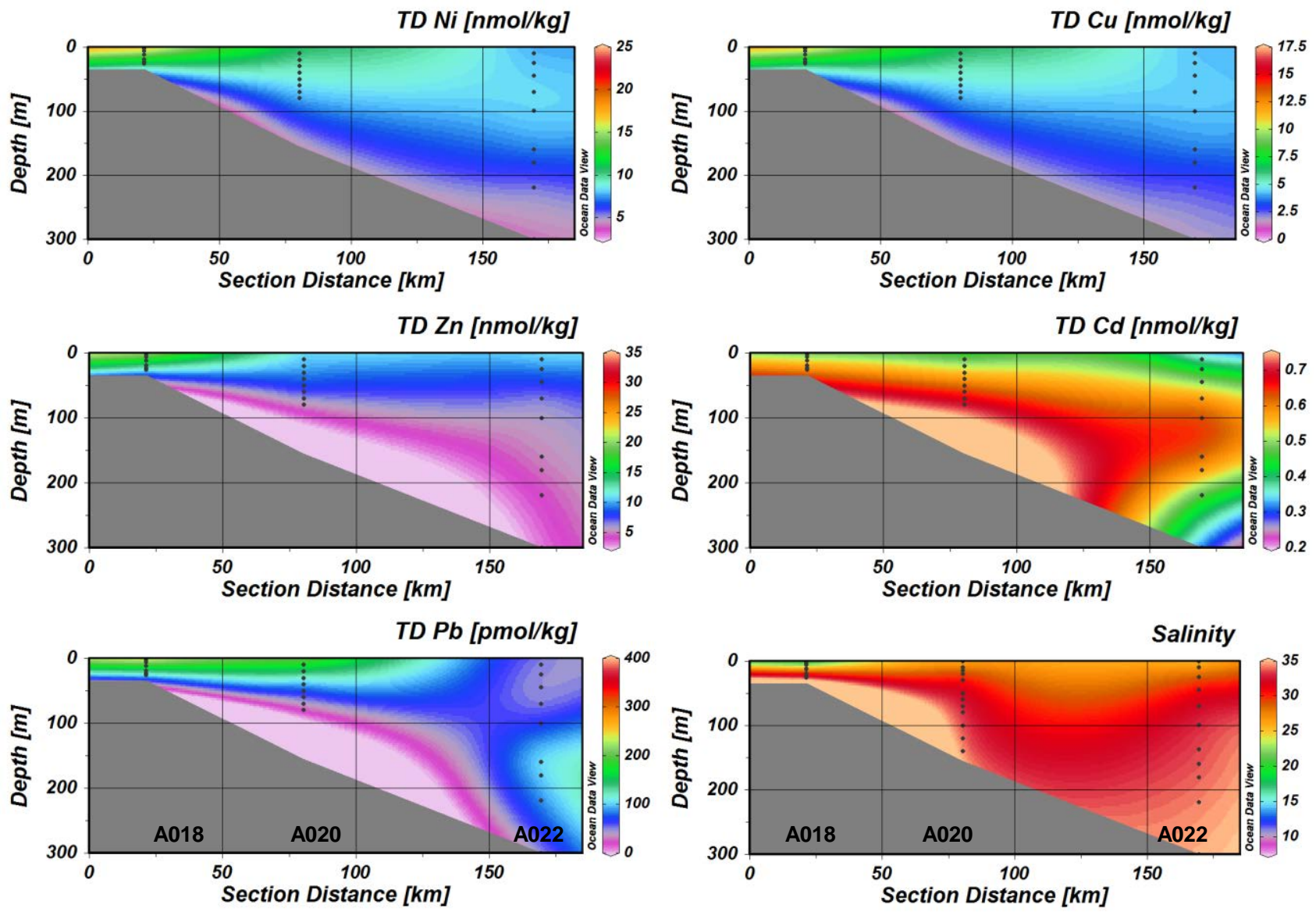

Figure 5 
TD Al [nmol/kg]
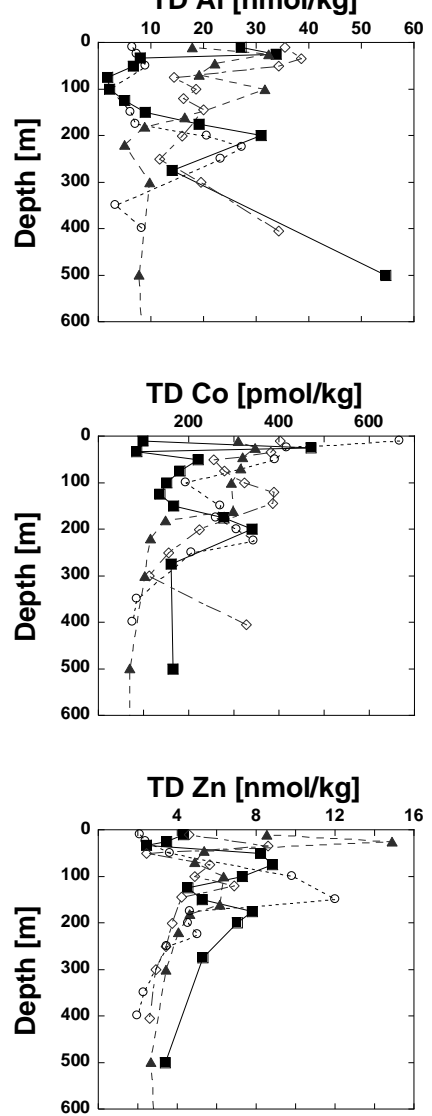

TD Mn [nmol/kg]
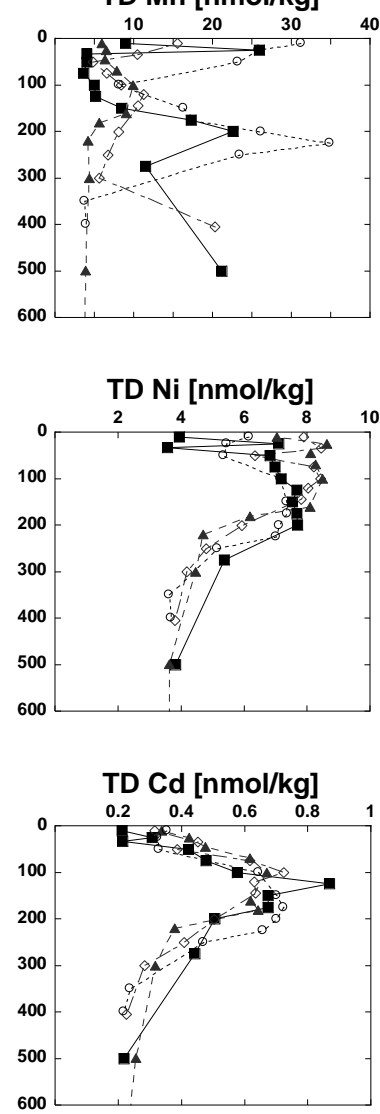

TD Fe [nmol/kg]
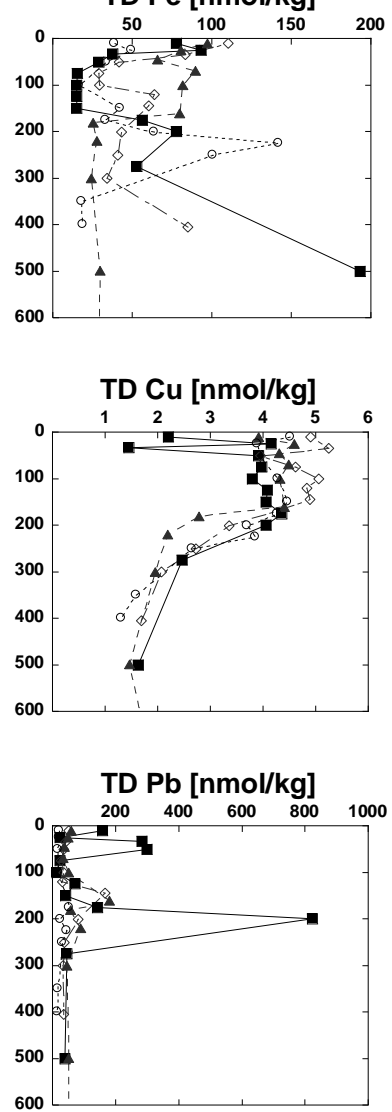

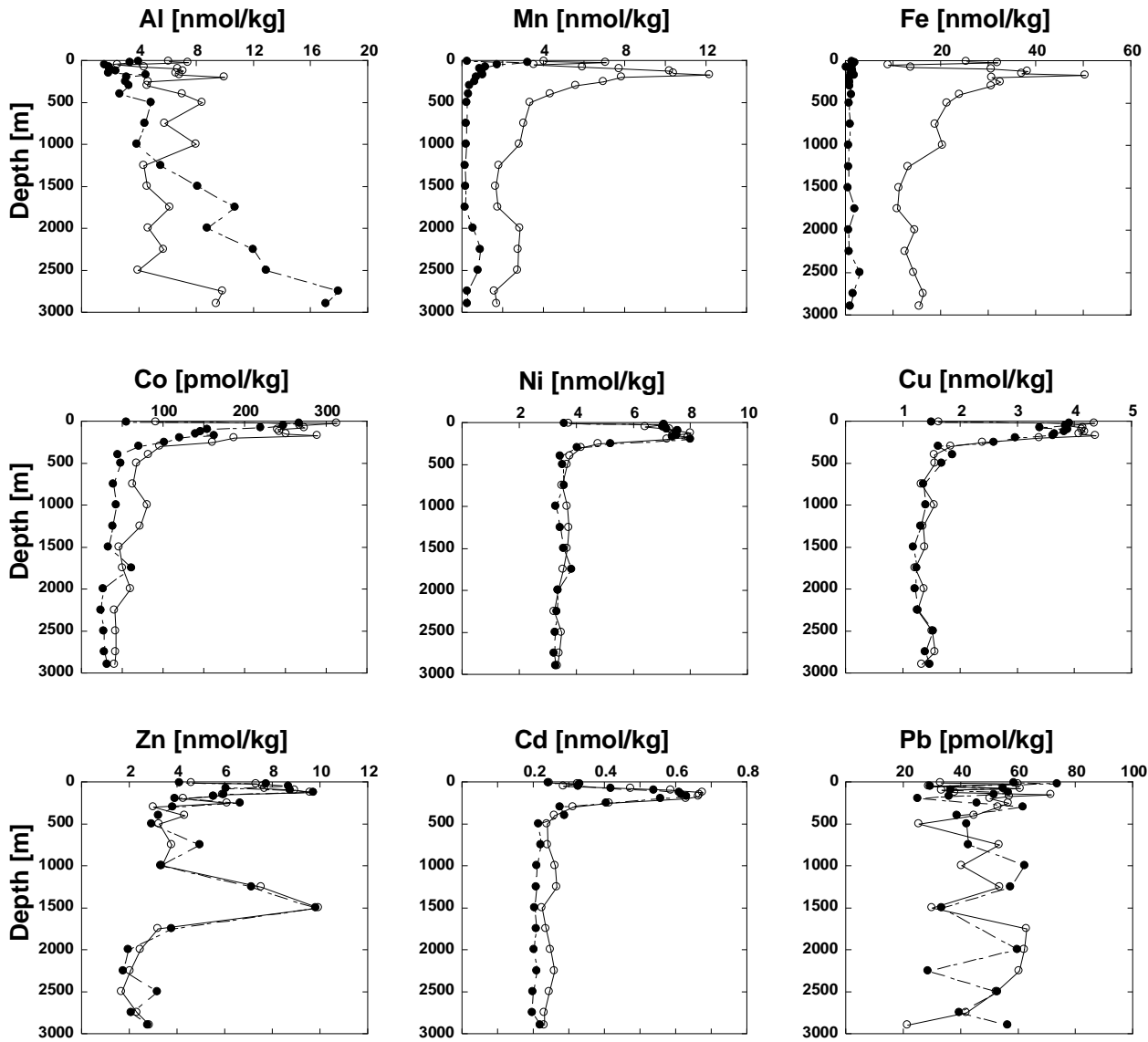


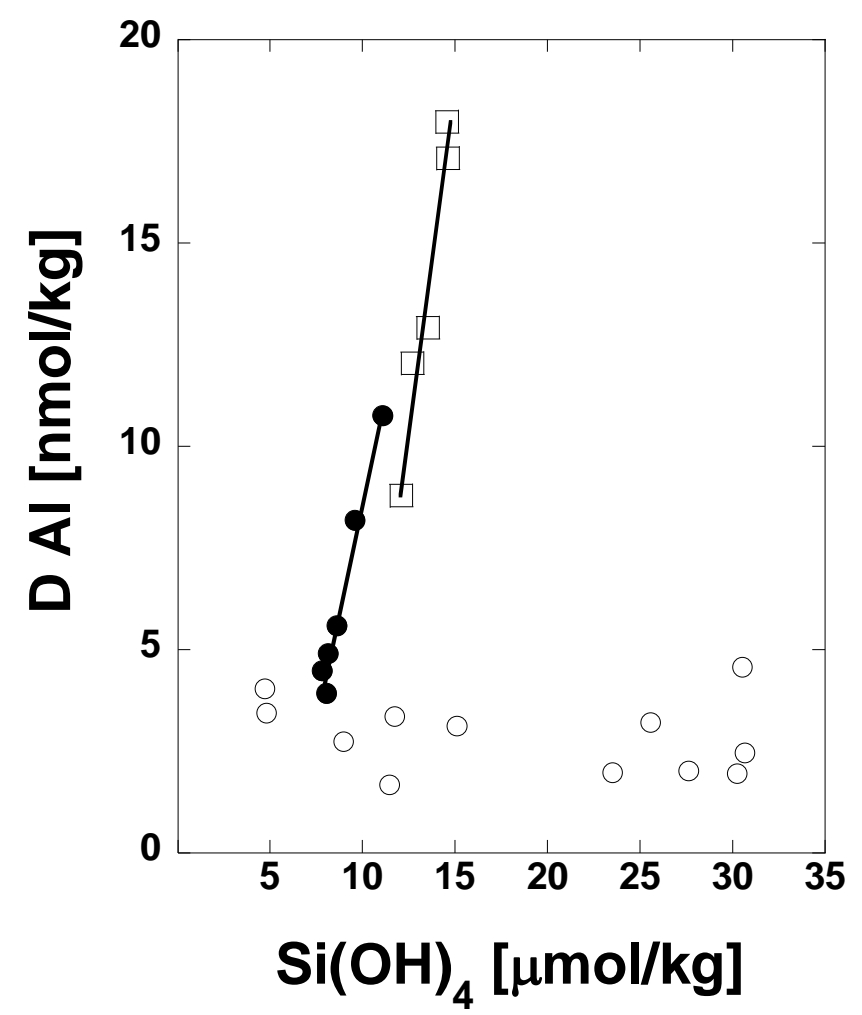

Figure 8 

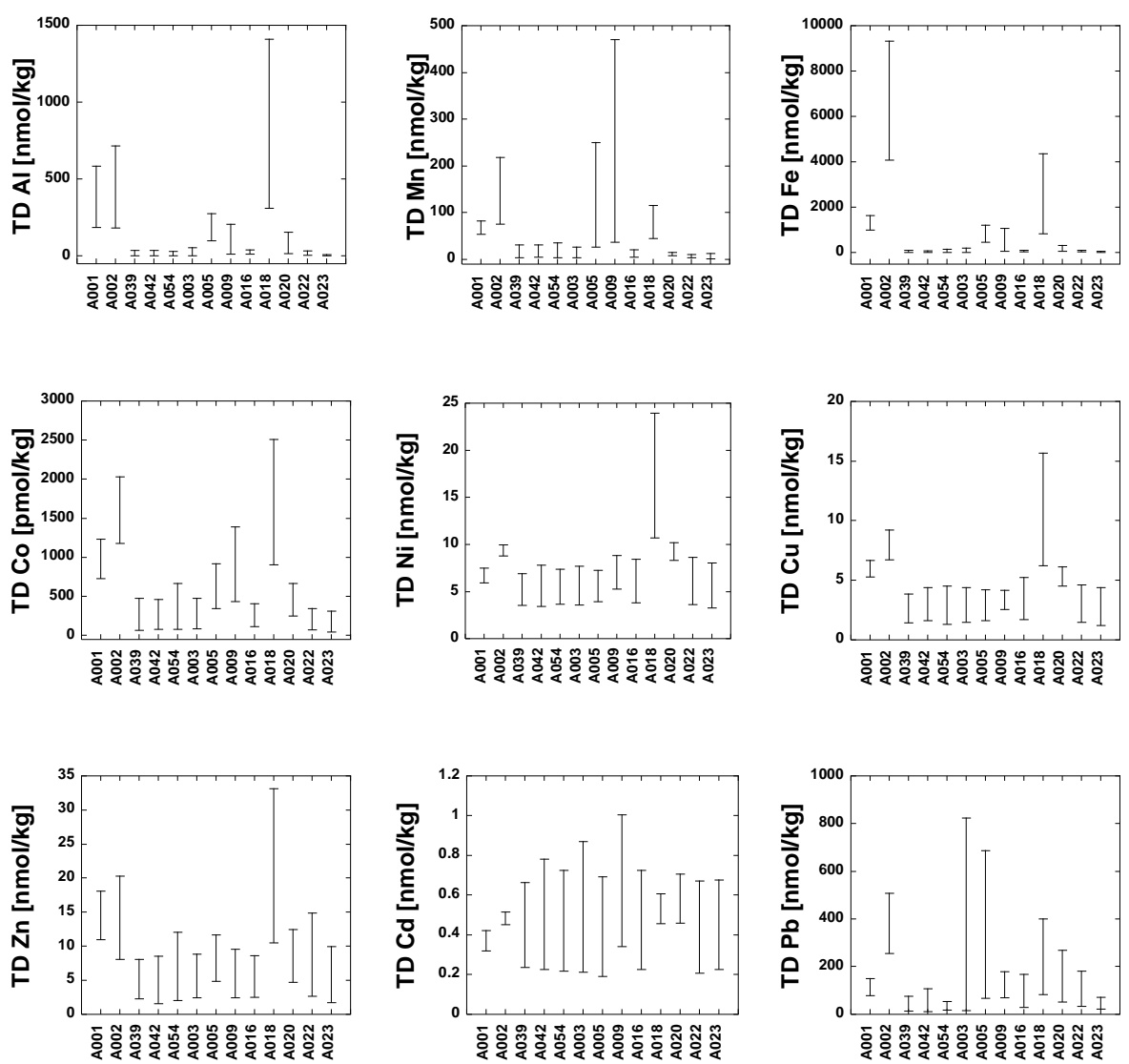

Figure 9 


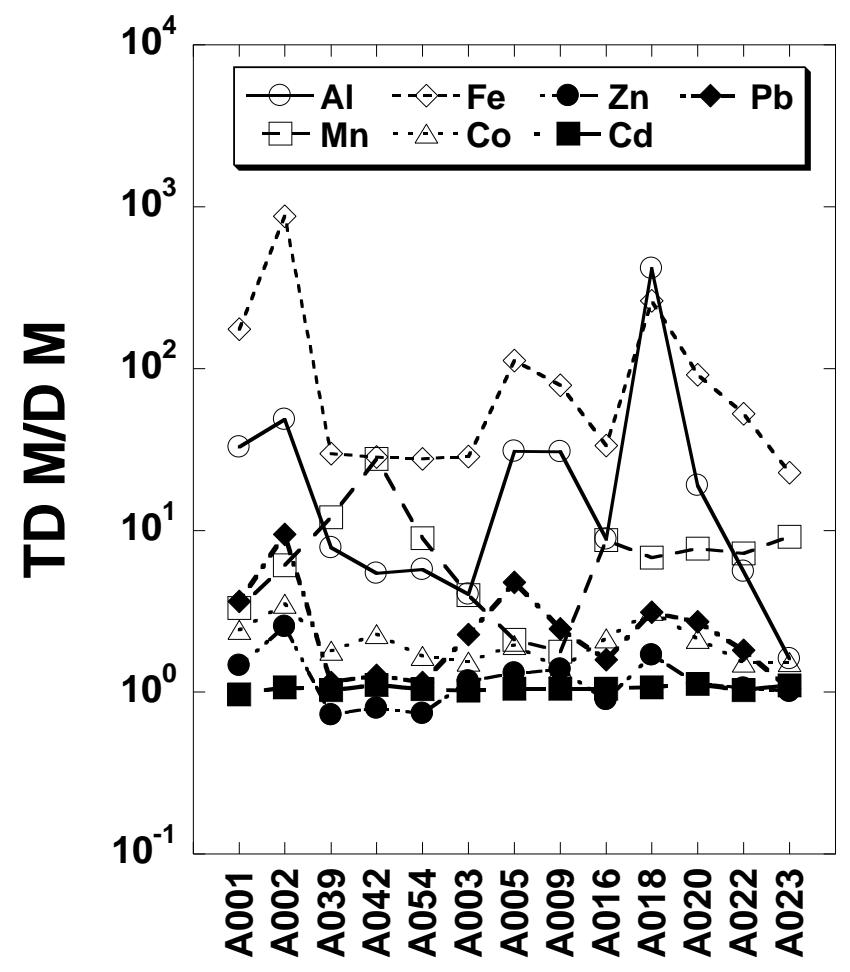

Figure 10 
(a)

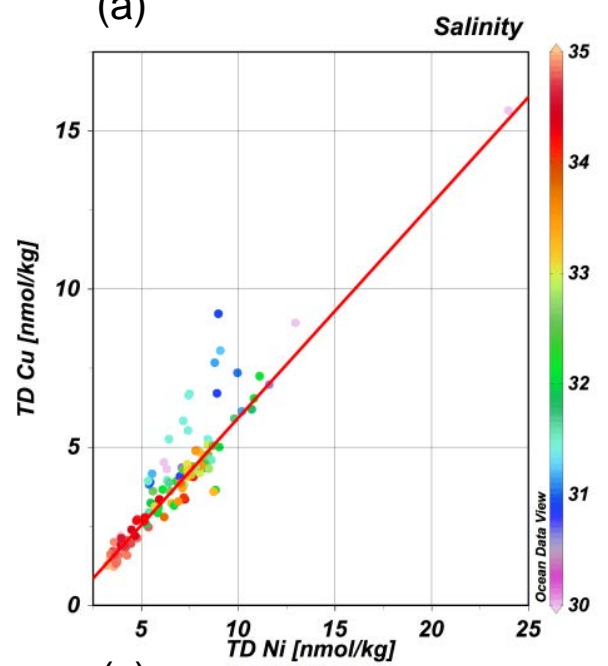

(c)

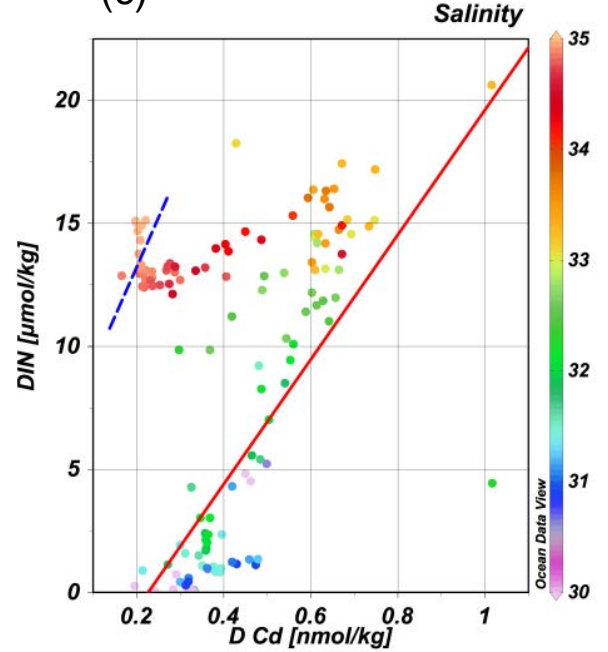

(b)

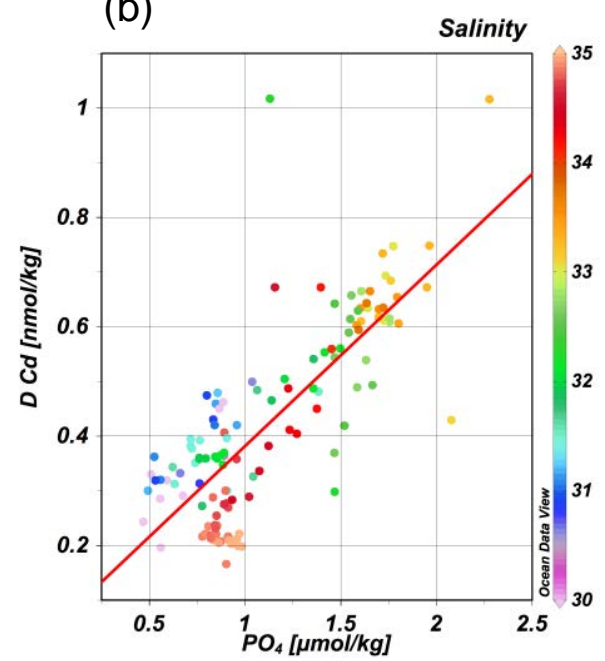

(d)

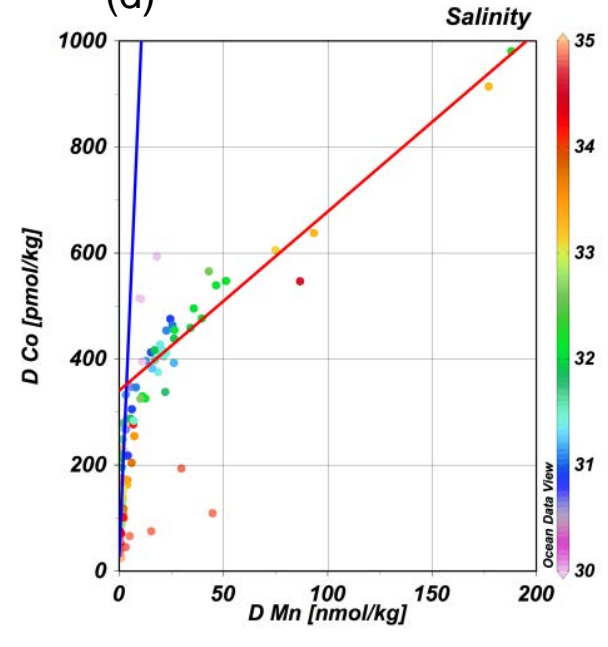




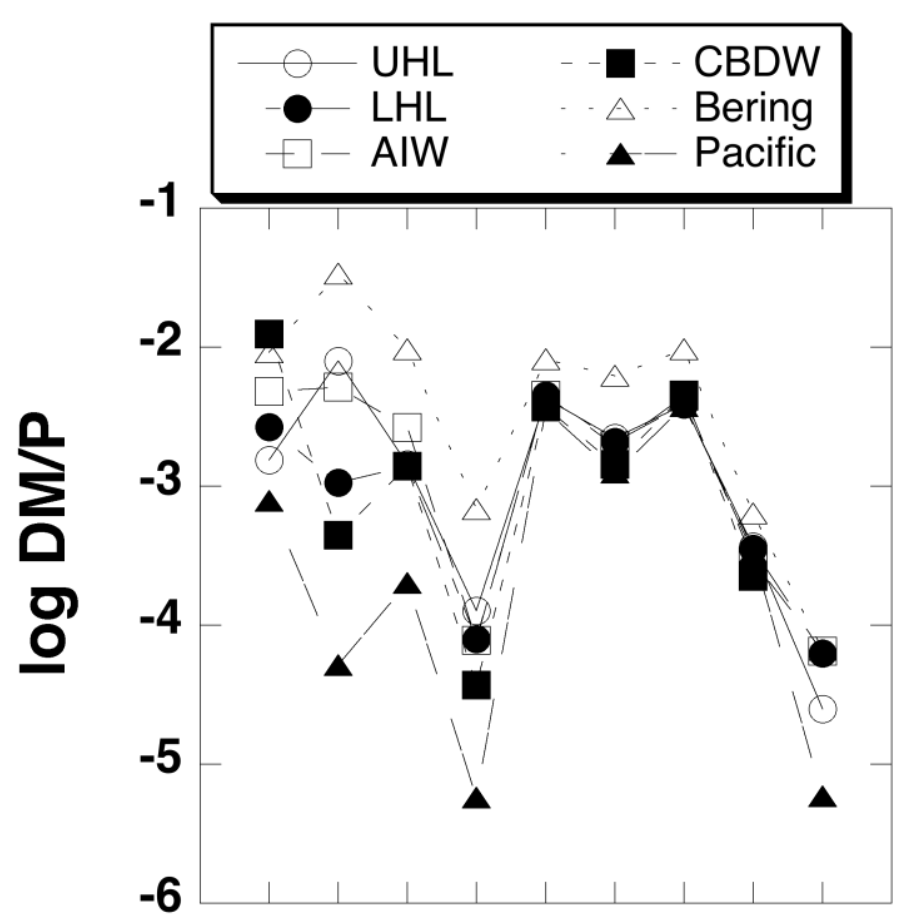

Al Mn Fe Co Ni Cu Zn Cd Pb

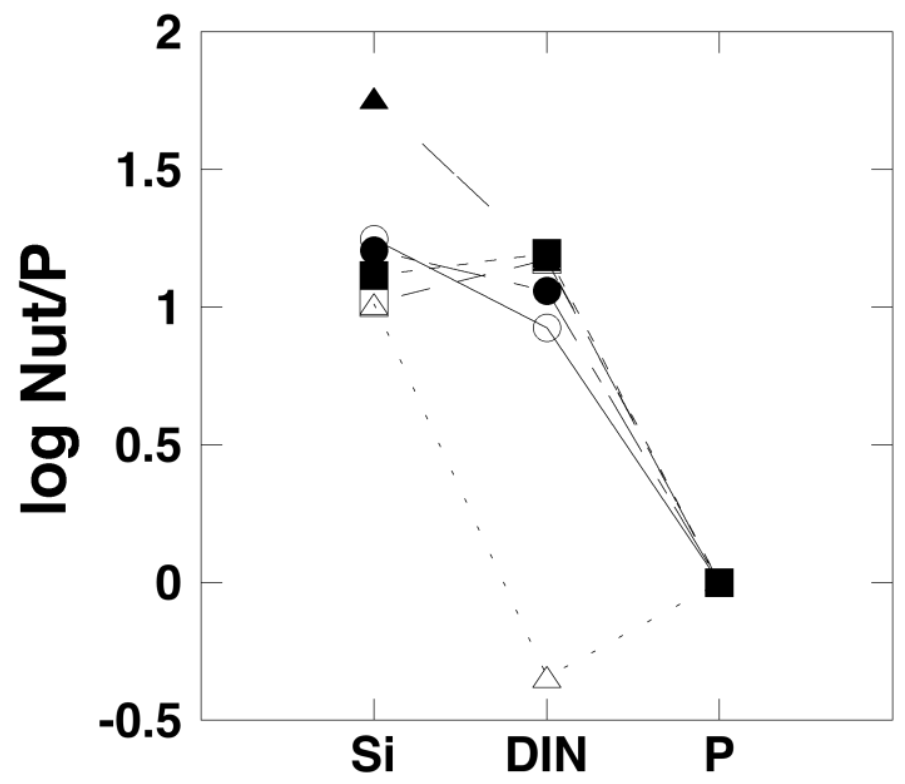

Figure 12 
Table 1 Concentrations of bioactive trace metals in each reagion

\begin{tabular}{|c|c|c|c|c|c|c|}
\hline & & $\begin{array}{l}\text { Bering Strait } \\
\text { min }-\max \end{array}$ & $\begin{array}{c}\text { Barrow Canyon }^{\mathrm{b}} \\
\min -\max \\
\end{array}$ & $\begin{array}{c}\text { Mackenzie } \text { Trough }^{\mathrm{c}} \\
\min -\max \end{array}$ & $\begin{array}{c}\text { Beaufort Sea Slope } \\
\text { min }-\max \end{array}$ & $\begin{array}{c}\text { Canada Basin } \\
\text { min }-\max \end{array}$ \\
\hline \multirow{2}{*}{$\mathrm{Al}[\mathrm{nmol} / \mathrm{kg}]$} & TD & $182-717$ & $12 \quad 275$ & $17-1410$ & $1.7-54.6$ & $2.53-9.99^{f}$ \\
\hline & $\mathrm{D}$ & $7.2-12.0$ & $1.8-52.4$ & $1.0-12.4$ & $0.9-10.4$ & $1.6-18.0$ \\
\hline \multirow{2}{*}{$\mathrm{Mn}[\mathrm{nmol} / \mathrm{kg}]$} & $\mathrm{TD}$ & $54-218$ & $26-470$ & $8-116$ & $3.1-34.9$ & $1.6-12.2$ \\
\hline & $\mathrm{D}$ & $12.9-25.6$ & $15-188$ & $0.9-18.1$ & $0.2-19.7$ & $0.15-3.25$ \\
\hline \multirow{2}{*}{$\mathrm{Fe}[\mathrm{nmol} / \mathrm{kg}]$} & TD & $998-9311$ & $52-1212$ & $60-4355$ & $10-193$ & $9.1-50.4$ \\
\hline & $\mathrm{D}$ & $4.9-10.4$ & $1.4-33.1$ & $1.0-24.9$ & $0.57-4.56$ & $0.19-3.14$ \\
\hline \multirow{2}{*}{ Co $[\mathrm{pmol} / \mathrm{kg}]$} & TD & $725-2033$ & $347-1390$ & $252-2505$ & $66-668$ & $41-313$ \\
\hline & $\mathrm{D}$ & $376-475$ & $75-980$ & $122-593$ & $33-515$ & $25-267$ \\
\hline \multirow{2}{*}{$\mathrm{Ni}[\mathrm{nmol} / \mathrm{kg}]$} & $\mathrm{TD}$ & $5.92-9.97$ & $3.91-8.83$ & $8.3-24.0$ & $3.41-8.62$ & $3.24-8.02$ \\
\hline & $\mathrm{D}$ & $4.88-7.59$ & $4.03-8.09$ & $6.2-15.1$ & $3.18-8.07$ & $3.23-8.02$ \\
\hline \multirow{2}{*}{$\mathrm{Cu}[\mathrm{nmol} / \mathrm{kg}]$} & $\mathrm{TD}$ & $5.25-9.22$ & $1.58-4.18$ & $4.5-15.6$ & $1.31-5.25$ & $1.22-4.38$ \\
\hline & $\mathrm{D}$ & $3.99-7.68$ & $1.76-4.60$ & $3.2-13.0$ & $1.00-4.63$ & $1.19-3.91$ \\
\hline \multirow{2}{*}{$\mathrm{Zn}[\mathrm{nmol} / \mathrm{kg}]$} & $\mathrm{TD}$ & $8.0-20.3$ & $2.4-11.7$ & $4.7-33.1$ & $1.5-14.9$ & $1.68-9.94$ \\
\hline & $\mathrm{D}$ & $2.5-13.7$ & $1.74-8.54$ & $3.3-12.0$ & $2.4-13.7$ & $1.76-9.82$ \\
\hline \multirow{2}{*}{$\mathrm{Cd}[\mathrm{nmol} / \mathrm{kg}]$} & $\mathrm{TD}$ & $0.319-0.515$ & $0.19-1.00$ & $0.456-0.707$ & $0.208-0.868$ & $0.225-0.675$ \\
\hline & $\mathrm{D}$ & $0.351-0.479$ & $0.17-1.02$ & $0.420-0.657$ & $0.196-0.747$ & $0.198-0.632$ \\
\hline \multirow{2}{*}{$\mathrm{Pb}[\mathrm{pmol} / \mathrm{kg}]$} & $\mathrm{TD}$ & $77-507$ & $66-686$ & $51-400$ & $10-823$ & $22-72^{g}$ \\
\hline & $\mathrm{D}$ & $19-55$ & $21-345$ & $24-111$ & $13-478$ & $25-74^{\mathrm{g}}$ \\
\hline
\end{tabular}

${ }^{\mathrm{a}}$ Stations A001 and A002; ${ }^{\mathrm{b}}$ stations A005 and A009; ' stations A018 and A020; ${ }^{\mathrm{s}}$ stations A003, A016, A022, A039, A042 and A054; ${ }^{\mathrm{e}}$ station A023.

${ }^{\mathrm{f}}$ The concentrations of TDAl bocome significantly lower than those of DAl only at this station. See text.

${ }^{\mathrm{f}}$ The vewrtical profiles of $\mathrm{TDPb}$ and $\mathrm{DPb}$ at this station are very erratic probably due to contamination or faults in determination. 
Table 2 Input of bioactive trace metals by the Pacific inflow water and the Mackenzie River water

\begin{tabular}{lcccc}
\hline & \multicolumn{2}{c}{ Pacific inflow water } & \multicolumn{2}{c}{ Mackenzie River water } \\
& conc $(\mathrm{mol} / \mathrm{kg})$ & input $(\mathrm{mol} / \mathrm{y})$ & conc $(\mathrm{mol} / \mathrm{kg})$ & input $(\mathrm{mol} / \mathrm{y})$ \\
\hline $\mathrm{Al}$ & $3.0 \mathrm{E}-07$ & $7.6 \mathrm{E}+09$ & $2.2 \mathrm{E}-06$ & $6.4 \mathrm{E}+08$ \\
$\mathrm{Mn}$ & $6.9 \mathrm{E}-08$ & $1.7 \mathrm{E}+09$ & $1.7 \mathrm{E}-07$ & $4.9 \mathrm{E}+07$ \\
$\mathrm{Fe}$ & $1.3 \mathrm{E}-06$ & $3.3 \mathrm{E}+10$ & $6.9 \mathrm{E}-06$ & $2.0 \mathrm{E}+09$ \\
$\mathrm{Co}$ & $9.8 \mathrm{E}-10$ & $2.5 \mathrm{E}+07$ & $3.7 \mathrm{E}-09$ & $1.1 \mathrm{E}+06$ \\
$\mathrm{Ni}$ & $7.0 \mathrm{E}-09$ & $1.8 \mathrm{E}+08$ & $3.5 \mathrm{E}-08$ & $1.0 \mathrm{E}+07$ \\
$\mathrm{Cu}$ & $6.0 \mathrm{E}-09$ & $1.5 \mathrm{E}+08$ & $2.3 \mathrm{E}-08$ & $6.7 \mathrm{E}+06$ \\
$\mathrm{Zn}$ & $1.4 \mathrm{E}-08$ & $3.5 \mathrm{E}+08$ & $5.0 \mathrm{E}-08$ & $1.5 \mathrm{E}+07$ \\
$\mathrm{Cd}$ & $3.7 \mathrm{E}-10$ & $9.3 \mathrm{E}+06$ & $4.5 \mathrm{E}-10$ & $1.3 \mathrm{E}+05$ \\
$\mathrm{~Pb}$ & $1.0 \mathrm{E}-10$ & $2.5 \mathrm{E}+06$ & $6.3 \mathrm{E}-10$ & $1.8 \mathrm{E}+05$ \\
\hline
\end{tabular}


Table 3 Compositions of water masses in the Chukchi and Beaufort Seas

\begin{tabular}{|c|c|c|c|c|}
\hline & $\begin{array}{c}\text { UHL }(\mathrm{n}=29) \\
\text { ave } \pm \text { sd }\end{array}$ & $\begin{array}{c}\text { LHL }(\mathrm{n}=9) \\
\text { ave } \pm \text { sd }\end{array}$ & $\begin{array}{c}\text { AIW }(\mathrm{n}=23) \\
\text { ave } \pm \text { sd }\end{array}$ & $\begin{array}{c}\text { CBDW }(\mathrm{n}=8) \\
\text { ave } \pm \text { sd }\end{array}$ \\
\hline Temperature & $-1.51 \pm 0.08$ & $-0.74 \pm 0.17$ & $0.46 \pm 0.19$ & $-0.46 \pm 0.10$ \\
\hline Salinity & $33.03 \pm 0.34$ & $34.25 \pm 0.14$ & $34.78 \pm 0.06$ & $34.94 \pm 0.02$ \\
\hline $\mathrm{O}_{2}[\mu \mathrm{mol} / \mathrm{kg}]$ & $291 \pm 15$ & $268 \pm 6$ & $291 \pm 7$ & $291 \pm 6$ \\
\hline $\mathrm{Si}(\mathrm{OH})_{4}[\mu \mathrm{mol} / \mathrm{kg}]$ & $30.6 \pm 4.4$ & $20.0 \pm 4.2$ & $9.0 \pm 1.5$ & $12.1 \pm 2.2$ \\
\hline $\mathrm{NO}_{3}[\mu \mathrm{mol} / \mathrm{kg}]$ & $13.8 \pm 1.5$ & $14.0 \pm 1.0$ & $12.8 \pm 0.3$ & $14.5 \pm 0.7$ \\
\hline $\mathrm{NO}_{2}[\mu \mathrm{mol} / \mathrm{kg}]$ & $0.04 \pm 0.06$ & $0.01 \pm 0.02$ & $0.00 \pm 0.01$ & $0.00 \pm 0.00$ \\
\hline $\mathrm{NH}_{4}[\mu \mathrm{mol} / \mathrm{kg}]$ & $0.71 \pm 1.67$ & $0.04 \pm 0.03$ & $0.07 \pm 0.09$ & $0.00 \pm 0.00$ \\
\hline $\mathrm{DIN}[\mu \mathrm{mol} / \mathrm{kg}]$ & $14.6 \pm 2.1$ & $14.0 \pm 1.0$ & $12.8 \pm 0.3$ & $14.5 \pm 0.7$ \\
\hline $\mathrm{PO}_{4}[\mu \mathrm{mol} / \mathrm{kg}]$ & $1.72 \pm 0.17$ & $1.23 \pm 0.17$ & $0.86 \pm 0.05$ & $0.93 \pm 0.05$ \\
\hline Chl. a $[\mu \mathrm{g} / \mathrm{kg}]$ & $0.10 \pm 0.14$ & $0.01 \pm 0.01$ & $0.04 \pm 0.05$ & \\
\hline TDAl [nmol/kg] & $33.3 \pm 45.8$ & $18.7 \pm 11.4$ & $41.3 \pm 78.4$ & \\
\hline $\mathrm{DAl}[\mathrm{nmol} / \mathrm{kg}]$ & $2.6 \pm 1.3$ & $3.3 \pm 2.7$ & $4.1 \pm 1.3$ & $11.7 \pm 4.3$ \\
\hline TDMn $[\mathrm{nmol} / \mathrm{kg}]$ & $40.9 \pm 95.1$ & $14.1 \pm 8.2$ & $13.2 \pm 18.3$ & $2.1 \pm 0.6$ \\
\hline $\mathrm{DMn}[\mathrm{nmol} / \mathrm{kg}]$ & $16.0 \pm 39.6$ & $1.4 \pm 2.0$ & $4.6 \pm 11.0$ & $0.4 \pm 0.3$ \\
\hline $\mathrm{TDFe}[\mathrm{nmol} / \mathrm{kg}]$ & $131 \pm 220$ & $53 \pm 28$ & $129 \pm 240$ & $14 \pm 2$ \\
\hline $\mathrm{DFe}[\mathrm{nmol} / \mathrm{kg}]$ & $2.7 \pm 3.4$ & $1.7 \pm 1.1$ & $2.3 \pm 2.5$ & $1.3 \pm 0.9$ \\
\hline TDCo $[\mathrm{pmol} / \mathrm{kg}]$ & $360 \pm 238$ & $180 \pm 73$ & $147 \pm 107$ & $49 \pm 11$ \\
\hline DCo $[\mathrm{pmol} / \mathrm{kg}]$ & $228 \pm 195$ & $102 \pm 72$ & $68 \pm 35$ & $34 \pm 12$ \\
\hline TDNi [nmol/kg] & $7.7 \pm 0.7$ & $5.4 \pm 1.3$ & $4.0 \pm 0.5$ & $3.5 \pm 0.2$ \\
\hline $\mathrm{DNi}[\mathrm{nmol} / \mathrm{kg}]$ & $7.3 \pm 0.6$ & $5.6 \pm 1.3$ & $3.9 \pm 0.4$ & $3.4 \pm 0.2$ \\
\hline $\mathrm{TDCu}[\mathrm{nmol} / \mathrm{kg}]$ & $4.2 \pm 0.5$ & $2.8 \pm 0.7$ & $1.7 \pm 0.4$ & $1.4 \pm 0.1$ \\
\hline $\mathrm{DCu}[\mathrm{nmol} / \mathrm{kg}]$ & $3.8 \pm 0.4$ & $2.6 \pm 0.6$ & $1.7 \pm 0.4$ & $1.3 \pm 0.1$ \\
\hline TDZn [nmol/kg] & $6.7 \pm 2.1$ & $4.2 \pm 1.3$ & $3.4 \pm 1.3$ & $4.0 \pm 3.0$ \\
\hline $\mathrm{DZn}[\mathrm{nmol} / \mathrm{kg}]$ & $6.6 \pm 2.5$ & $4.7 \pm 0.5$ & $3.8 \pm 1.0$ & $4.1 \pm 2.9$ \\
\hline $\mathrm{TDCd}[\mathrm{nmol} / \mathrm{kg}]$ & $0.67 \pm 0.10$ & $0.45 \pm 0.10$ & $0.26 \pm 0.06$ & $0.24 \pm 0.01$ \\
\hline $\mathrm{DCd}[\mathrm{nmol} / \mathrm{kg}]$ & $0.63 \pm 0.10$ & $0.44 \pm 0.12$ & $0.25 \pm 0.05$ & $0.21 \pm 0.01$ \\
\hline $\mathrm{TDPb}[\mathrm{pmol} / \mathrm{kg}]$ & $68 \pm 50$ & $144 \pm 257$ & $60 \pm 79$ & \\
\hline $\mathrm{DPb}[\mathrm{pmol} / \mathrm{kg}]$ & $43 \pm 22$ & $83 \pm 148$ & $57 \pm 71$ & \\
\hline
\end{tabular}

